\title{
Taxonomic review and phylogenetic analysis of Enchodontoidei (Teleostei: Aulopiformes)
}

\author{
HILDA M.A. SILVA and VALÉRIA GALLO \\ Laboratório de Sistemática e Biogeografia, Departamento de Zoologia, Instituto de Biologia, \\ Universidade do Estado do Rio de Janeiro, Rua São Francisco Xavier, 524, Maracanã, \\ 20550-013 Rio de Janeiro, RJ, Brasil \\ Manuscript received on September 24, 2010; accepted for publication on December 22, 2010
}

\begin{abstract}
Enchodontoidei are extinct marine teleost fishes with a long temporal range and a wide geographic distribution. As there has been no comprehensive phylogenetic study of this taxon, we performed a parsimony analysis using a data matrix with 87 characters, 31 terminal taxa for ingroup, and three taxa for outgroup. The analysis produced 93 equally parsimonious trees $(\mathrm{L}=437$ steps; $\mathrm{CI}=0.24$; $\mathrm{RI}=0.49)$. The topology of the majority rule consensus tree was: (Sardinioides + Hemisaurida $+($ Nardorex $+($ Atolvorator $+($ Protostomias + Yabrudichthys $)+($ Apateopholis + $($ Serrilepis $+($ Halec + Phylactocephalus $)+($ Cimolichthys $+($ Prionolepis $+(($ Eurypholis + Saurorhamphus $)+$ $($ Enchodus $+($ Paleolycus + Parenchodus $))))))+(($ Ichthyotringa + Apateodus $)+($ Rharbichthys $+($ Trachinocephalus + $(($ Apuliadercetis + Brazilodercetis $)+($ Benthesikyme $+($ Cyranichthys + Robertichthys $)+($ Dercetis + Ophidercetis $))$ $+($ Caudadercetis $+($ Pelargorhynchus $+($ Nardodercetis $+($ Rhynchodercetis $+($ Dercetoides + Hastichthys $))))))$. The group Enchodontoidei is not monophyletic. Dercetidae form a clade supported by the presence of very reduced neural spines and possess a new composition. Enchodontidae are monophyletic by the presence of middorsal scutes, and Rharbichthys was excluded. Halecidae possess a new composition, with the exclusion of Hemisaurida. This taxon and Nardorex are Aulopiformes incertae sedis.
\end{abstract}

Key words: Aulopiformes, Enchodontoidei, phylogeny, taxonomy.

\section{INTRODUCTION}

Enchodontoidei are extinct marine teleosts generally with an elongate body and long and narrow rod-like maxilla included in the mouth gape (Nelson 1994). They possess a long temporal range, extending from the Early Cretaceous to the Early Eocene, and a wide geographic distribution in sedimentary deposits of South America (e.g., Bolivia and Brazil), Africa (e.g., Democratic Republic of Congo, Egypt, and Morocco), Asia (e.g., Arabian Peninsula, India, Israel, Japan, and Lebanon), Europe (e.g., Belgium, England, Germany, Holland, Italy, and Sweden), and North America (Canada, Mexico, and United States) (e.g., Goody 1969, Chalifa

Correspondence to: Hilda Maria Andrade da Silva

E-mail: hmasilva@yahoo.com.br
1996, Fielitz 2004, Figueiredo and Gallo 2006, Gallo et al. 2006).

The taxon was erected by Berg (1937) as a suborder, which included only the family Enchodontidae. According to this author, enchodontid fishes were similar to the members of the suborder Stomiatoidei also created by him, but the enchodontids bear a median row of dorsal scutes and their vertebrae do not possess parapophyses. Goody (1969) accomplished a comprehensive review of certain Late Cretaceous teleosteans, considering Enchodontoidei as part of the order Salmoniformes, together with three other suborders, Ichthyotringoidei, Cimolichthyoidei, and Halecoidei.

Rosen (1973) erected the order Aulopiformes comprising 15 living families, and the suborder Alepisau- 
roidei with 15 fossil genera, without dividing them systematically (i.e., Ichthyotringa, Apateodus, Apateopholis, Cimolichthys, Dercetis, Rhynchodercetis, Pelargorhynchus, Prionolepis, Enchodus, Palaeolycus, Eurypholis, Saurorhamphus, Halec, Phylactocephalus, and Hemisaurida), as well as the fossil genera incertae sedis of the superfamily Synodontoidea, Sardinius and Volcichthys.

Nelson (1994) recognized the order Aulopiformes by Rosen (1973), as well as the suborders proposed by Goody (1969) as superfamilies, putting them in a single suborder, Enchodontoidei, composed of four superfamilies: Enchodontoidea (Enchodus, Parenchodus, Palaeolycus, Eurypholis, and Saurorhamphus), Cimolichthyoidea (Cimolichthys, Prionolepis, Benthesikyme, Cyranichthys, Dercetis, Dercetoides, Pelargorhynchus, Rhynchodercetis, and Stratodus), Halecoidea (Halec, Hemisaurida, and Phylactocephalus) and Ichthyotringoidea (Ichthyotringa and Apateodus). However, this classification was not developed in a phylogenetic framework.

Baldwin and Johnson (1996) accomplished a cladistic analysis of Aulopiformes, including only extant taxa. The authors maintained the monophyly of the taxon and added synapomorphies to those proposed by Rosen (1973), which are mainly related to the morphology of the dorsal portion of the gill arches. Their new synapomorphies are from the intermuscular system, internal soft anatomy, pigmentation pattern of larvae, and morphology of the pelvic girdle. Most of these features are very difficult to assess in fossil specimens.

Sato and Nakabo (2002) accomplished a phylogenetic analysis of living Aulopiformes based on morphological and molecular data. They divided it into the suborders Synodontoidei, Chlorophthalmoidei, Alepisauroidei, and Giganturoidei. Moreover, the authors proposed a new family of Aulopiformes (i.e., Paraulopidae).

Fielitz (2004) and Gallo et al. (2005) proposed hypotheses of the phylogenetic relationships of some fossil Aulopiformes (Enchodontoidea and Dercetidae, respectively).

Nelson (2006) placed the extinct aulopiforms in three suborders: Ichthyotringoidei, comprising the families Ichthyotringidae, Dercetidae, and Prionolepidae; Halecoidei, with a single family, Halecidae; and Alepisauroidei, with two families, Cimolichthyidae and
Enchodontidae. The extant aulopiforms were classified in Synodontoidei (with four families), Chlorophthalmoidei (with six families), and Giganturoidei (with two families). Additionally, four living families were placed in the suborder Alepisauroidei.

In fact, the assemblage of extinct aulopiforms defined by Nelson (2006) corresponds to Enchodontoidei sensu Nelson (1994). However, Nelson (2006) did not discuss his reasons for disregarding the name Enchodontoidei and put its members in Alepisauroidei, Ichthyotringoidei, and Halecoidei. Moreover, Enchodontoidei were considered in the cladistic analysis of Dercetidae (Gallo et al. 2005), as well as in a preliminary approach by Silva and Gallo (2007). As there has not been a recent comprehensive phylogenetic study of Enchodontoidei, we review their classification history and provide a new cladistic analysis.

\section{SYSTEMATIC HISTORY OF ENCHODONTOIDEI}

In this paper we use the general classification of Nelson (1994), except for the family Enchodontidae (sensu Fielitz 2004).

\section{SUPERFAMILY ICHTHYOTRINGOIDEA}

According to Goody (1969), Ichthyotringoidea comprises two closely related families, Ichthyotringidae and Apateopholidae. The author considered mainly primitive features of the body and caudal skeleton, as well as a derived feature related to the rostral region. $\mathrm{He}$ stated that, despite the similarities shared by the taxa, Apateopholidae should be the more advanced taxon.

Family Ichthyotringidae. The family Ichthyotringidae (Table I) was created by Jordan (1905) to contain a single genus (i.e., Ichthyotringa). Goody (1969) positioned the family in the suborder Ichthyotringoidei. Later, Nelson (1994) included the taxon in the suborder Enchodontoidei together with other fossil aulopiforms. The generic epithet Ichthyotringa was created by Cope (1878) to replace the genus Rhinellus of Agassiz (1844), which was pre-occupied. The genus Ichthyotringa includes the following species: Ichthyotringa furcata (Agassiz, 1844), I. tenuirostris Cope, 1878, I. damoni (Davis, 1887), I. ferox (Davis, 1887), I. delicata (Hay, 1903), and I. africana (Arambourg, 1954). Forey et 
al. (2003), in the general list of fossil fishes from Lebanon, placed Apateopholis in the family Ichthyotringidae, but remarked that at least one species of Apateopholis is often misinterpreted as a species of the closely related Ichthyotringa. Only more recently a new ichthyotringoidei was reported to the El Doctor Formation in the Albian-Cenomanian of Mexico, I. mexicana Fielitz and González Rodríguez, 2008.

Goody (1969) ranked Apateodus as an addendum (incertae sedis) to the Ichthyotringidae with a single species (A. striatus Woodward, 1901). Nelson (1994, 2006) placed Apateodus in Apateopholidae, but he did not report the taxonomic status of Apateopholis. In Frickhinger (1995), the latter was considered an ichthyotringid and the former was not mentioned. Forey et al. (2003) positioned Apateopholis in the family Ichthyotringidae. Taverne (2004) maintained Apateodus and two other genera of Cretaceous alepisauroids (Yabrudichthys and Rharbichthys) as family incertae sedis. However, the same author (Taverne 2006c) suggested to exclude Apateodus from Ichthyotringidae. Fielitz and González Rodríguez (2008) accomplished a cladistic analysis of Ichthyotringoidea and placed Apateodus tentatively among the species of Ichthyotringa. More recently, Fielitz and Shimada (2009) described a new species of Apateodus (A. busseni) suggesting that the genus needs revision, but ranking it in Ichthyotringidae.

Family Apateopholidae. The family Apateopholidae (Table I) was erected by Goody (1969) to include only the genus Apateopholis, with two species [A. laniatus (Davis, 1887); A. lanceolatus Woodward, 1901]. The genus Apateopholis was erected by Woodward (1891) to substitute Rhinellus by Davis (1887), which was posteriorly allocated in Belonostomus by Woodward (1888). Ten years after the creation of the genus, Woodward (1901) put Apateopholis in synonymy with Prionolepis. Goody (1969) revalidated the generic epithet Apateopholis with the single species Apateopholis laniatus.

\section{Superfamily CimolichthyoideA}

This superfamily includes three families (i.e., Cimolichthyidae, Dercetidae, and Prionolepididae). According to Goody (1969), Cimolichthyidae and Dercetidae show a great similarity regarding the structures of the skull and body, especially in the rostral region. Moreover, general body squamation is lacking and two or three rows of isolated scutes are present on the flanks. Regarding the family Prionolepididae, the author pointed out some problems concerning its taxonomic placement. Unlike Woodward (1901), who assigned the genus Prionolepis to the Enchodontidae, Goody (1969) considered it closely related to dercetids and cimolichthyids.

Family Cimolichthyidae. The family (Table II) was erected by Goody (1969) to include the single genus Cimolichthys, which was designated by Leidy (1857) with the species C. levesiensis. Cope (1872), studying specimens from Niobrara (USA), recognized five species of Cimolichthys: C. nepaholica, C. sulcatus, $C$. semianceps, C. contracta, and C. merrillii. Later, Hay (1903) recognized only the species $C$. nepaholica, as other species were based mainly on isolated teeth and fragments of the jaws.

Family Dercetidae. Traditionally the creation of this family is attributed to Pictet (1850). However, he did not use the name Dercetidae, defining only a Dercetis group with $D$. tenuis, D. triqueter, and D. linguifer. As far as we know, the name Dercetidae was used for the first time by Woodward (1901).

The following taxa are regarded as valid in the most recent revisions of the Dercetidae (e.g., Taverne 1987, 1991, 2005a, b, 2006b, Chalifa 1989a, Gallo et al. 2005, Blanco et al. 2008) and in general fossil fish lists (e.g., Frickhinger 1995, Forey et al. 2003): Apuliadercetis tyleri Taverne, 2006a; Benthesikyme armatus (von der Marck, 1863); B. rostralis (Davis, 1887); B. gracilis (Signeux, 1954); Brazilodercetis longirostris Figueiredo and Gallo, 2006; Caudadercetis bannikovi Taverne, 2006b; Cyranichthys ornatissimus (Casier, 1965); Dercetis elongatus (Agassiz, 1837); D. triqueter Pictet, 1850; Dercetoides venator Chalifa, 1989a; Hastichthys gracilis (Chalifa, 1989a); Leccedercetis longirostris Taverne, 2008; Nardodercetis vandewallei Taverne, 2005a; Ophidercetis italiensis Taverne, 2005b; Pelargorhynchus dercetiformis von der Marck, 1858; Rhynchodercetis hakelensis (Pictet and Humbert, 1866); R. yovanovitchi Arambourg, 1943; R. gortanii (d'Erasmo, 1946); R. regio Blanco and Alvarado-Ortega, 2006; 
TABLE I

Occurrences of the Superfamily Ichthyotringoidea $(\mathrm{Fm}=$ Formation; NDA $=$ no data available $)$.

\begin{tabular}{|c|c|c|c|}
\hline Taxon & Provenance & Age & Selected References \\
\hline Ichthyotringa africana & Jebel Tselfat & Cenomanian & $\begin{array}{l}\text { Murray (2000), } \\
\text { Forey et al. (2003), } \\
\text { Taverne (2006c) }\end{array}$ \\
\hline I. africana & Cinto Euganeo & Cenomanian-Turonian & Taverne (2006c) \\
\hline I. damoni & Sahel Alma & Santonian & $\begin{array}{l}\text { Forey et al. (2003), } \\
\text { Taverne (2006c) }\end{array}$ \\
\hline I. delicata & Hakel and Hajula & Cenomanian & $\begin{array}{l}\text { Goody (1969), } \\
\text { Forey et al. (2003), } \\
\text { Taverne (2006c) }\end{array}$ \\
\hline I. ferox & Sahel Alma & Santonian & $\begin{array}{l}\text { Forey et al. (2003), } \\
\text { Taverne (2006c) }\end{array}$ \\
\hline I. furcata & Sahel Alma & Santonian & $\begin{array}{l}\text { Goody (1969), } \\
\text { Forey et al. (2003), } \\
\text { Taverne (2006c) }\end{array}$ \\
\hline I. furcata & Sendenhorst & Santonian & Goody (1969) \\
\hline I. furcata & Niedersachsen & Santonian & Kriwet and Gloy (1995) \\
\hline I. tenuirostris & Dakota and Nebraska & Upper Cretaceous & Taverne $(2006 \mathrm{c})$ \\
\hline I. mexicana & El Doctor Fm. & Albian-Cenomanian & $\begin{array}{l}\text { Fielitz and } \\
\text { González Rodríguez (2008) }\end{array}$ \\
\hline Apateopholis laniatus & Hakel & Middle Cenomanian & Goody (1969) \\
\hline A. laniatus & Namoura & Middle Cenomanian & Forey et al. (2003) \\
\hline A. lanceolatus & English Chalk & Turonian & Forey et al. (2003) \\
\hline Apateodus striatus & Lewes & Turonian & Goody (1969) \\
\hline A. striatus & NDA & Maastrichtian & Kruizinga (1924) \\
\hline Apateodus sp. & Kaskapau Fm. & Turonian & Wilson and Chalifa (1989) \\
\hline Apateodus sp. & Mumbay Fm. & Cretaceous-Tertiary & Cripps et al. (2005) \\
\hline Apateodus sp. & Akli Fm. & Paleocene-Eocene & Rana et al. (2005) \\
\hline Apateodus sp. & El Molino Fm. & $\begin{array}{l}\text { Upper Campanian- } \\
\text { Lower Paleocene }\end{array}$ & $\begin{array}{l}\text { Gayet (1991), } \\
\text { Jaillard et al. (1993) }\end{array}$ \\
\hline
\end{tabular}

R. serpentinus (Hay, 1903); Robertichthys riograndensis Blanco-Piñon and Alvarado-Ortega, 2005; and Scandiadercetis limhamnensis (Davis, 1890) (Table II).

Chalifa (1989a) stated that Dercetidae are a "relatively primitive" group, considering the presence of few apomorphies. She carried out a phylogenetic analysis of this taxon and recognized it as a monophyletic group, comprising the following clades: (Dercetis, (Pelargorhynchus, (Dercetoides, Rhynchodercetis))).

Taverne $(1987,1991)$ considered Dercetidae to be a clade of Stomiiformes. In reviewing the material studied by Chalifa (1989a) and discussing the relationships of genera, Taverne (1991) assumed a monophyletic condition for this family and used 33 characters to define it. He placed Benthesikyme as the most primitive genus, possessing most of (or all) these 33 "generalized conditions". Taverne (1991) also "distributed" 40 "apomorphies" to genera and groups of genera in the family.

Gallo et al. (2005) accomplished a cladistic analysis of the family Dercetidae, using an outgroup composed of Enchodontoidei taxa. The authors obtained only one tree supporting the monophyly of Dercetidae, based on two synapomorphies: absence of a longitudinal opercular crest and reduced neural spine. They also 
TABLE II

Occurrences of the Superfamily Cimolichthyoidea $(\mathrm{Fm}=$ Formation; NDA $=$ no data available $)$.

\begin{tabular}{|c|c|c|c|}
\hline Taxon & Provenance & Age & Selected References \\
\hline Cimolichthys levesiensis & Chalk of Sussex & Turonian-Senonian & Goody (1969) \\
\hline C. levesiensis & NDA & Cretaceous & Leriche $(1902,1906)$ \\
\hline C. cf. levesiensis & Kaskapau Fm. & Turonian & Wilson and Chalifa (1989) \\
\hline C. nepaholica & Niobrara Fm. & Coniacian-Santonian & Goody $(1969,1970)$ \\
\hline C. nepaholica & Pierre Shale & Campanian & Goody $(1969,1970)$ \\
\hline Cimolichthys sp. & Lac des Bois & Turonian & Fielitz (1996) \\
\hline Apuliadercetis tyleri & Nardò & $\begin{array}{l}\text { Campanian- } \\
\text { Maastrichtian }\end{array}$ & Taverne (2006a) \\
\hline Benthesikyme armatus & Westphalia & Campanian & Taverne $(2005 b)$ \\
\hline B. gracilis & NDA & Santonian & Taverne (2005b) \\
\hline B. rostralis & NDA & Santonian & Taverne $(2005 b)$ \\
\hline Brazilodercetis longirostris & Atlântida Fm. & Turonian & Figueiredo and Gallo (2006) \\
\hline Caudadercetis bannikovi & Nardò & $\begin{array}{l}\text { Campanian- } \\
\text { Maastrichtian }\end{array}$ & Taverne $(2006 b)$ \\
\hline Cyranichthys ornatissimus & Kipala & Cenomanian & Taverne (1987) \\
\hline Dercetis elongatus & NDA & Turonian-Senonian & Taverne (2005b) \\
\hline D. triqueter & Sahel Alma & Santonian & $\begin{array}{l}\text { Goody (1969), } \\
\text { Taverne (2005b) }\end{array}$ \\
\hline Dercetis sp. & Harrana & Maastrichtian & Kaddumi (2006) \\
\hline Dercetoides venator & Amminadav Fm. & Lower Cenomanian & Chalifa (1989a) \\
\hline Dercetoides sp. & Kaskapau Fm. & Turonian & Wilson and Chalifa (1989) \\
\hline Hastichthys gracilis & Amminadav Fm. & Lower Cenomanian & Chalifa (1989a) \\
\hline H. cf. gracilis & Namoura & Middle Cenomanian & Forey et al. (2003) \\
\hline Leccedercetis longirostris & Nardò & $\begin{array}{l}\text { Campanian- } \\
\text { Maastrichtian }\end{array}$ & Taverne (2008) \\
\hline Nardodercetis vandewallei & Nardò & $\begin{array}{l}\text { Campanian- } \\
\text { Maastrichtian }\end{array}$ & Taverne $(2005 a)$ \\
\hline Ophidercetis italiensis & Nardò & $\begin{array}{l}\text { Campanian- } \\
\text { Maastrichtian } \\
\end{array}$ & Taverne (2005b) \\
\hline Pelargorhynchus dercetiformis & Sedenhorst & Upper Senonian & Goody (1969) \\
\hline Rhynchodercetis hakelensis & Hakel & Middle Cenomanian & $\begin{array}{l}\text { Goody (1969), } \\
\text { Forey et al. (2003) }\end{array}$ \\
\hline R. yovanovitchi & Jebel Tselfat & Lower Cenomanian & $\begin{array}{l}\text { Arambourg (1954), } \\
\text { Goody (1969), } \\
\text { Taverne (1987) }\end{array}$ \\
\hline R. yovanovitchi & Messina & Cenomanian & Leonardi (1966) \\
\hline$R$. cf. yovanovitchi & Namoura & Middle Cenomanian & Forey et al. (2003) \\
\hline R. gortanii & Trieste-Komen & Lower Cenomanian & $\begin{array}{l}\text { Goody (1969), } \\
\text { Forey et al. (2003) }\end{array}$ \\
\hline R. regio & Agua Nueva Fm. & Turonian & $\begin{array}{l}\text { Blanco and } \\
\text { Alvarado-Ortega (2006) }\end{array}$ \\
\hline R. serpentinus & Hakel and Hajula & Middle Cenomanian & Forey et al. (2003) \\
\hline
\end{tabular}


TABLE II (continuation)

\begin{tabular}{llll}
\hline Taxon & Provenance & Age & Selected References \\
\hline Rhynchodercetis sp. & Trieste-Komen & Campanian & Cavin et al. (2000) \\
\hline Rhynchodercetis sp. & Cinto Euganeo & Coniacian-Santonian & Sorbini (1976) \\
\hline Rhynchodercetis sp. & Polazzo & Lower Senonian & Rigo (1999) \\
\hline Rhynchodercetis sp. & Daoura & Cenomanian & Cavin and Dutheil (1999) \\
\hline Robertichthys riograndensis & Agua Nueva & Lower Turonian & Blanco-Piñon and \\
& & & Alvarado-Ortega (2005) \\
\hline Scandiadercetis limhamnensis & Saltholm Limestone & Danian & Taverne (2005b) \\
\hline Prionolepis angustus & Tormarp & Upper Albian- & Lundgren (1889) \\
& & Lower Cenomanian & \\
\hline P. angustus & English Chalk & Cenomanian-Turonian & Forey et al. (2003) \\
\hline P. cataphractus & Hakel and Hajula & Middle Cenomanian & Forey et al. (2003) \\
\hline
\end{tabular}

verified that some of the superfamilies proposed by Nelson (1994) are not monophyletic. Taking into account the description of four new genera of Dercetidae from Nardò, Italy (Taverne 2005a, b, 2006a, b), as well as the new diagnoses of Dercetis and Benthesikyme (Taverne 2005b), Taverne (2006b) proposed a phylogenetic review of the Dercetidae, in which he provided a list of 43 plesiomorphies to this family. In the phylogenetic hypothesis furnished by Blanco et al. (2008), the monophyly of Dercetidae was confirmed and it was supported by the same synapomorphies shown in Gallo et al. (2005).

Dercetis was the first described genus of Dercetidae. It was created by Agassiz (1834) to accommodate the species $D$. scutatus. The taxon was briefly described on the basis of a single and almost complete specimen. The holotype was lost or destroyed, without being figured (Siegfried 1954, Goody 1969, Taverne 2005b). Pictet (1850) erected Dercetis triqueter and D. linguifer. Later, von der Marck (1863) identified a new genus within Dercetidae to include two new species, Leptotrachelus armatus and L. sagittatus. Pictet and Humbert (1866) synonymized D. triqueter and D. linguifer with Leptotrachelus triqueter. Siegfried (1966) redescribed the material by von der Marck (1863) and transferred the Leptotrachelus spp. for the genus Dercetis (D. armatus and D. sagittatus). Goody (1969) redescribed D. triqueter and claimed that $D$. linguifer was clearly $D$. triqueter.

Pelargorhynchus dercetiformis was erected by von der Marck (1858) based on several but poorly preserved specimens from Germany. There is no record of this genus in any other locality.

The genus Benthesikyme was created by White and Moy-Thomas (1940), including new species of Leptotrachelus described by several authors at the end of the nineteenth century and during the twentieth century. Taverne (2005b) furnished a comprehensive review of the genera Dercetis, Leptotrachelus, and Benthesikyme, in which L. sagittatus is probably a synonym of $D$. elongatus, $L$. virgulatus of $D$. triqueter, and L. longipinnis of Benthesikyme gracilis. The taxonomic status of D. reussi, D. latiscutatus, D. maximus, and $L$. serpentinus was also discussed but not in a conclusive way. Yet, Taverne $(2005 \mathrm{a}, \mathrm{b})$ erected three new monotypic genera within the family Dercetidae, Ophidercetis (O. italiensis), Nardodercetis (N. vandewallei), and Scandiadercetis ( $S$. limhamnensis). The latter had been proposed originally by Davis (1890) as Dercetis limhamnensis.

The genus Rhynchodercetis was erected by Arambourg (1943), comprising a single species, $R$. yovanovitchi, which is very abundant in deposits from the Lower Cenomanian of Morocco. Later, other Rhynchodercetis spp. were described: $R$. hakelensis (Pictet and Humbert, 1866); R. gortanii (d'Erasmo, 1946); and $R$. regio Blanco and Alvarado-Ortega, 2006. Chalifa (1989a) described Dercetoides venator and Rhynchodercetis gracilis. The latter was renamed as Hastichthys gracilis by Taverne (1991).

Blanco-Piñon and Alvarado-Ortega (2005) briefly described Robertichthys riograndensis, which is the sec- 
ond record of Dercetidae in the Turonian of Mexico. Blanco et al. (2008) provided a redescription of this taxon, as well as a discussion on its relationships.

Figueiredo and Gallo (2006) described Brazilodercetis longirostris, which is the first record of the family in South America.

Family Prionolepididae. The genus Prionolepis was created by Egerton (in Dixon 1850) with only one species, P. angustus. Later, Pictet and Humbert (1866) included one more species in the genus, $P$. cataphractus. Goody (1969) reviewed $P$. cataphractus and proposed the family Prionolepididae (Table II).

\section{SUPERFAMILY ENCHODONTOIDEA}

Family Enchodontidae. Previously to Woodward (1901), the genera assigned to Enchodontoidea were allocated in different families (Agassiz 1835, Pictet 1850, Cope 1872, 1874). The first attempt to classify the enchodontoids in a separate group was proposed by Woodward (1901), in which the author erected the family Enchodontidae and put it in the Isospondyli. He divided the family into two main groups based on the presence or the absence of a single tooth in palatine. In the first group, the author included the genera Enchodus, Palaeolycus, Eurypholis, and Saurorhamphus; the second consisted of the genera Halec, Cimolichthys, Prionolepis, Leptecodon, and Pantopholis. However, Woodward (1901) stated that the living families more closely related to the Enchodontidae were Alepisauridae and Odontostomidae, which possess the border of the upper jaw formed exclusively by the premaxilla, the maxilla being untoothed and excluded from the mouth gape.

After Woodward (1901), there was a long debate about the relationships of enchodontids and living fish families. Jordan (1905), Gregory (1933), and Arambourg (1954) agreed with the hypothesis of Woodward (1901) regarding the relationships of enchodontids and alepisaurids, but they positioned Enchodontidae in the suborder Iniomi. On the other hand, Regan (1911) and Romer (1945) rejected the hypothesis of Woodward (1901) and allocated the family into the Stomiatoidei, belonging to the suborder Isospondyli. Berg (1940) also rejected the enchodontids plus alepisaurids hypothesis and put enchodontids in the suborder Enchodontoidei into the Clupeiformes, as synonym of Isospondyli. The generic composition of Enchodontidae remained stable for some time, except for Halec, which was moved to the family Halecidae by Goody (1969), and for the inclusion of Rharbichthys by Arambourg (1954).

Goody (1969) accomplished a comprehensive review of the Enchodontidae, including the genera Enchodus and Palaeolycus. Also, he created the family Eurypholidae into Enchodontoidei to comprise the genera Eurypholis and Saurorhamphus.

Sorbini (1976) proposed a relationship between Rharbichthys and Cimolichthys. Taverne (1985) studied Rharbichthys and stated that it probably possessed close affinity with the halecids regarding the general proportions and the head shape.

Although the monophyly of Enchodontidae seems to be widely accepted, the previous diagnoses (e.g., Goody 1969, Rosen 1973, Chalifa 1989b) were not deduced from cladistic analyses.

Recently, Fielitz (2004) tested the monophyly of the family Enchodontidae, including living and extinct aulopiforms. The clade is supported by three synapomorphies: single dermopalatine tooth, dermopalatine bone with same length or shorter than the tooth, and interopercle absent. Alepisauridae appear in the analysis as the sister group of the clade formed by the extinct Aulopiformes. Enchodontidae were divided into four subfamilies: Rharbichthinae (with Rharbichthys), Palaeolycinae (with Palaeolycus), Eurypholinae (with Eurypholis and Saurorhamphus) and Enchodontinae (with Enchodus). The genus Parenchodus was put in synonymy with Enchodus.

The subfamily Rharbichthinae (Table III) is monotypic, being represented only by Rharbichthys ferox Arambourg, 1954. This species was considered by several authors as belonging to the Enchodontidae (e.g., Bertin and Arambourg 1958, Leonardi 1966, Goody, 1969), whereas Sorbini (1976) classified it in the family Cimolichthyidae. Yet, Taverne (1985) claimed that R. ferox is an alepisauroid.

The subfamily Palaeolycinae (Table III) is monotypic, comprising only Palaeolycus dreginensis described by von der Marck (1863). Later, it was reviewed by Siegfried (1954), who pointed out morphological similarities and putative relationships with the 
TABLE III

Occurrences of the Superfamily Enchodontoidea $(F m=$ Formation; NDA $=$ no data available $)$.

\begin{tabular}{|c|c|c|c|}
\hline Taxon & Provenance & Age & Selected References \\
\hline Rharbichthys ferox & Jebel Tselfat & Upper Senonian & $\begin{array}{l}\text { Arambourg (1954), } \\
\text { Murray (2000) }\end{array}$ \\
\hline R. ferox & Messina & Cenomanian & $\begin{array}{l}\text { Leonardi (1966), } \\
\text { Figueiredo et al. (2001) }\end{array}$ \\
\hline R. ferox & Cinto Euganeo & Cenomanian-Turonian & $\begin{array}{l}\text { Sorbini (1976), } \\
\text { Figueiredo et al. (2001) }\end{array}$ \\
\hline$R$. cf. ferox & Atlântida Fm. & Turonian & Figueiredo et al. (2001) \\
\hline Palaeolycus dreginensis & Sedenhorst & Upper Senonian & $\begin{array}{l}\text { Goody (1969), } \\
\text { Siegfried (1954) }\end{array}$ \\
\hline eurypholid & Harrana & Maastrichtian & Kaddumi (2006) \\
\hline Eurypholis boissieri & Hakel and Hajula & Middle Cenomanian & Goody (1969) \\
\hline E. boissieri & Namoura & Middle Cenomanian & Forey et al. (2003) \\
\hline E. pulchellus & English Chalk & Cenomanian-Turonian & $\begin{array}{l}\text { Goody (1969), } \\
\text { Forey et al. (2003) }\end{array}$ \\
\hline E. japonicus & Izumi & Campanian & $\begin{array}{l}\text { Yabumoto and } \\
\text { Uyeno (1994) }\end{array}$ \\
\hline Saurorhamphus freyeri & Trieste-Komen & Lower Cenomanian & Goody (1969) \\
\hline S. judeaensis & Amminadav Fm. & Lower Cenomanian & Chalifa (1985) \\
\hline Enchodus sp. & El Molino Fm. & Maastrichtian-Danian & Gayet (1991) \\
\hline Enchodus sp. & Trieste-Komen & Turonian-Campanian & Cavin et al. (2000) \\
\hline Enchodus sp. & Polazzo & Lower Senonian & Rigo (1999) \\
\hline Enchodus sp. & Atlântida Fm. & Lower Turonian & Gallo et al. (2006) \\
\hline Enchodus sp. & Coqueiro Seco Fm. & Barremian & Coelho (2004) \\
\hline Enchodus sp. & Lac des Bois & Turonian & Fielitz (1996) \\
\hline Enchodus sp. & Ghareb & $\begin{array}{l}\text { Campanian- } \\
\text { Maastrichtian }\end{array}$ & Chalifa (1996) \\
\hline Enchodus sp. & Niedersachsen & Lower Turonian & Kriwet and Gloy (1995) \\
\hline Enchodus sp. & Goulmima & Lower Turonian & Cavin (1999) \\
\hline Enchodus sp. & Iwaki & Cretaceous & $\begin{array}{l}\text { Yabumoto and } \\
\text { Uyeno (1994) }\end{array}$ \\
\hline E. brevis & Amminadav Fm. & Lower Cenomanian & Chalifa (1989b) \\
\hline E. bursauxi & Ouled Abdoun & Maastrichtian- Danian & Arambourg (1952) \\
\hline E. bursauxi & West Desert & Upper Campanian & Chalifa (1996) \\
\hline E. bursauxi & NDA & Maastrichtian & Chalifa (1996) \\
\hline E. bursauxi & Ghareb & Campanian & Chalifa (1996) \\
\hline E. bursauxi & Bentiaba & Upper Cretaceous & Jacobs et al. (2006) \\
\hline E. dentex & Trieste-Komen & Cenomanian & $\begin{array}{l}\text { Chalifa (1996), } \\
\text { Forey et al. (2003) }\end{array}$ \\
\hline E. dirus & several localities & Maastrichtian & Goody (1976) \\
\hline E. elegans & Ouled Abdoun & Maastrichtian- Danian & Arambourg (1952) \\
\hline E. elegans & Gramame Fm. & Maastrichtian & $\begin{array}{l}\text { Rebouças and } \\
\text { Silva Santos (1956), } \\
\text { Coelho (2004) }\end{array}$ \\
\hline
\end{tabular}


TABLE III (continuation)

\begin{tabular}{|c|c|c|c|}
\hline Taxon & Provenance & Age & Selected References \\
\hline E. elegans & NDA & Maastrichtian & Chalifa (1996) \\
\hline E. elegans & Bentiaba & Upper Cretaceous & Jacobs et al. (2006) \\
\hline E. elegans & Palmyrides & Lower Maastrichtian & Bardet et al. (2000) \\
\hline \multirow[t]{2}{*}{ E. elegans } & \multirow[t]{2}{*}{ Ruseifa } & \multirow[t]{2}{*}{ Maastrichtian } & Bardet and \\
\hline & & & Pereda Superbiola (2002) \\
\hline E. cf. elegans & Iembe & Upper Cretaceous & Jacobs et al. (2006) \\
\hline E. faujasi & NDA & Maastrichtian & Goody (1968) \\
\hline E. faujasi & Jadet & Maastrichtian & Breton et al. (1995) \\
\hline E. faujasi & Bentiaba & Upper Cretaceous & Jacobs et al. (2006) \\
\hline \multirow{2}{*}{ E. ferox } & \multirow[t]{2}{*}{ several localities } & Campanian- & \multirow[t]{2}{*}{ Goody (1976) } \\
\hline & & Maastrichtian & \\
\hline E. gladiolus & several localities & Coniacian-Santonian & Goody (1976) \\
\hline E. gracilis & Sedenhorst & Senonian & Chalifa (1996) \\
\hline E. lewesiensis & Lewes & Turonian-Senonian & Chalifa (1996) \\
\hline E. libycus & West Desert & Upper Campanian & Chalifa (1996) \\
\hline E. libycus & Ghareb & Campanian & Chalifa (1996) \\
\hline \multirow[t]{2}{*}{ E. libycus } & \multirow[t]{2}{*}{ Gramame Fm. } & \multirow[t]{2}{*}{ Maastrichtian } & Rebouças and \\
\hline & & & Silva Santos (1956) \\
\hline \multirow[t]{3}{*}{ E. libycus } & \multirow[t]{3}{*}{ Cotinguiba Fm. } & \multirow[t]{3}{*}{ Cenomanian-Coniacian } & Silva Santos and \\
\hline & & & Salgado (1969), \\
\hline & & & Coelho (2004) \\
\hline E. libycus & Ouled Abdoun & Maastrichtian-Danian & Arambourg (1952) \\
\hline E. libycus & NDA & Maastrichtian & Chalifa (1996) \\
\hline E. longidens & Sahel Alma & Senonian & Forey et al. (2003) \\
\hline E. cf. longidens & Akli Fm. & Paleocene-Eocene & Rana et al. (2005) \\
\hline \multirow[t]{3}{*}{ E. longipectoralis } & \multirow[t]{3}{*}{ Cotinguiba Fm. } & \multirow[t]{3}{*}{ Cenomanian-Coniacian } & Silva Santos and \\
\hline & & & Salgado (1969), \\
\hline & & & Coelho (2004) \\
\hline \multirow[t]{2}{*}{ E. lycodon } & \multirow[t]{2}{*}{ Trieste-Komen } & \multirow[t]{2}{*}{ Cenomanian } & Chalifa (1996), \\
\hline & & & Forey et al. (2003) \\
\hline E. macropterus & Sedenhorst & Upper Senonian & Siegfried (1954) \\
\hline E. major & Sahel Alma & Senonian & Chalifa (1996) \\
\hline \multirow[t]{2}{*}{ E. cf. major } & \multirow[t]{2}{*}{ Trieste-Komen } & \multirow[t]{2}{*}{ Cenomanian } & Chalifa (1996), \\
\hline & & & Forey et al. (2003) \\
\hline \multirow[t]{2}{*}{ E. marchesettii } & \multirow[t]{2}{*}{ Hakel and Hajula } & \multirow[t]{2}{*}{ Middle Cenomanian } & Goody (1969), \\
\hline & & & Chalifa (1996) \\
\hline E. mecoanalis & Namoura & Middle Cenomanian & Forey et al. (2003) \\
\hline \multirow[t]{3}{*}{ E. oliverai } & Gramame Fm. & Maastrichtian & Rebouças and \\
\hline & & & Silva Santos (1956), \\
\hline & & & Coelho (2004) \\
\hline E. oliverai & Cotinguiba Fm. & Cenomanian-Coniacian & Coelho (2004) \\
\hline E. petrosus & several localities & Coniacian-Santonian & Goody (1976) \\
\hline E. shumardi & several localities & Cenomanian- & Goody (1976) \\
\hline & & Maastrichtian & \\
\hline
\end{tabular}


TABLE III (continuation)

\begin{tabular}{llll}
\hline Taxon & Provenance & Age & Selected References \\
\hline E. cf. shumardi & Kaskapau Fm. & Turonian & Wilson and Chalifa (1989) \\
\hline E. subaequilateralis & Gramame Fm. & Maastrichtian & $\begin{array}{l}\text { Gallo-da-Silva (1993), } \\
\text { Coelho (2004) }\end{array}$ \\
\hline E. venator & Jebel Tselfat & Lower Cenomanian & $\begin{array}{l}\text { Arambourg (1954), } \\
\text { Chalifa (1996) }\end{array}$ \\
\hline E. venator & & & Leonardi (1966) \\
\hline E. cf. venator & Messina & Cenomanian & Sorbini (1976) \\
\hline E. zinensis & Cinto Euganeo & Cenomanian-Turonian & Chalifa (1996) \\
\hline Parenchodus longipterygius & Ghareb & Upper Campanian- & \\
& & Lower Maastrichtian & \\
\hline
\end{tabular}

extant genus Odontostomus. This genus is in synonymy with Evermanella, which is in the family Evermannellidae of the suborder Alepisauroidei.

The subfamily Eurypholinae (Table III) was originally proposed as a family (Eurypholidae) by Goody (1969) to encompass the genus Eurypholis by Pictet (1850). This genus comprises only the type-species ( $E$. boissieri Pictet, 1850) and another one initially proposed as Enchodus pulchellus by Woodward (1901), but later redefined by Goody (1969) as Eurypholis pulchellus.

Nelson (1994) placed the family Eurypholidae in the superfamily Enchodontoidea in the suborder Enchodontoidei.

Fielitz (2004) suggested the arrangement of the genera Eurypholis and Saurorhamphus in the subfamily Eurypholinae.

Saurorhamphus freyeri was originally described by Heckel (1850), and transferred to the genus Eurypholis by Woodward (1901). However, d'Erasmo (1912) claimed that Saurorhamphus was actually a distinct genus, closely related to Eurypholis. Another species, S. judeaensis, was described by Chalifa (1985).

The subfamily Enchodontinae (Table III) includes only the genus Enchodus Agassiz, 1835, containing, however, about 24 valid species, most of them erected on the basis of fragmentary material (isolated teeth or pieces of jaws), as follows: Enchodus brevis Chalifa, 1989b; E. bursauxi (Arambourg, 1952); E. dentex (Heckel, 1856); E. dirus (Leidy, 1857); E. faujasi Goody, 1968; E. ferox Leidy, 1855; E. gladiolus (Cope, 1872); E. gracilis (von der Marck, 1858); E. lewesiensis (Mantell, 1822); E. libycus (Quaas, 1902); E. longidens (Pictet, 1850); E. longipectoralis (Schaeffer, 1947); E. longipterygius (Raab and Chalifa, 1987); E. lycodon Kner, 1867; E. macropterus (von der Marck, 1863); E. major Davis, 1887; E. marchesettii (Kramberger, 1895); E. mecoanalis Forey, Yi, Patterson and Davies, 2003; E. oliverai Maury, 1930; E. petrosus Cope, 1874; E. shumardi Leidy, 1856; E. subaequilateralis Cope, 1886 (=E. elegans); E. venator Arambourg, 1954; E. zinensis Chalifa, 1996 (e.g., Goody 1976, Chalifa 1996, Forey et al. 2003, Fielitz 2004).

Parenchodus longipterygius was described by Raab and Chalifa (1987) as belonging to the family Enchodontidae. The authors suggested a relationship with the genus Enchodus, due to similarities in some structures of the head, the absence of scales, and the fusion of the elements of the caudal fin. Fielitz (2004) put the genus in synonymy with Enchodus.

\section{SUPERFAMILY HALECOIDEA}

Family Halecidae. The family Halecidae (Table IV) was originally proposed by Agassiz (1834) including forms similar to the clupeoids and salmonoids. The grouping and its name were used only by Pictet (1850) and Davis (1887), being disused later. The family was re-erected by Goody (1969) into the suborder Halecoidei containing three genera: Halec, Phylactocephalus, and Hemisaurida. Nelson (1994) put Halecidae in the superfamily Halecoidea in the suborder Enchodontoidei. Later, Nelson (2006) opted to use the suborder Halecoidei by Goody (1969). 
TABLE IV

Occurrences of the Superfamily Halecoidea.

\begin{tabular}{llll}
\hline Taxon & Provenance & Age & Selected References \\
\hline Halec sternbergi & Bohemia & $\begin{array}{l}\text { Middle and } \\
\text { Upper Turonian }\end{array}$ & Goody (1969) \\
\hline H. eupterygius & English Chalk & Turonian & $\begin{array}{l}\text { Goody (1969), } \\
\text { Forey et al. (2003) }\end{array}$ \\
\hline H. haueri & Lesina & Lower Cenomanian & Goody (1969), \\
& & & Forey et al. (2003) \\
\hline Phylactocephalus microlepis & Hakel and Hajula & Middle Cenomanian & Goody (1969), \\
& & & Forey et al. (2003) \\
\hline Hemisaurida hakelensis & Hakel & Middle Cenomanian & Goody (1969), \\
& & & Forey et al. (2003) \\
\hline H. neocomiensis & Trieste-Komen & Lower Cenomanian & Goody (1969), \\
& & & Forey et al. (2003) \\
\hline
\end{tabular}

TABLE V

Occurrence of incertae sedis taxa $(\mathrm{Fm}=$ Formation $)$.

\begin{tabular}{llll}
\hline Taxon & Provenance & Age & Selected References \\
\hline Nardorex zorzini & Nardò & $\begin{array}{l}\text { Campanian- } \\
\text { Maastrichtian }\end{array}$ & Taverne (2004) \\
\hline Serrilepis longidens & Amminadav Fm. & Middle Cenomanian & Chalifa (1989c) \\
\hline S. prymnostrigos & Namoura & Middle Cenomanian & Forey et al. (2003) \\
\hline S. minor & Namoura & Middle Cenomanian & Forey et al. (2003) \\
\hline Yabrudichthys & Amminadav Fm. & Lower Cenomanian & Chalifa (1989c) \\
\hline Atolvorator longipectoralis & Coqueiro Seco Fm. & Barremian & Gallo and Coelho (2008) \\
\hline
\end{tabular}

Regarding the genus Halec, there are three valid species: H. sternbergi Agassiz, 1844 (type-species), H. eupterygius (Dixon, 1850), and H. haueri (Bassani, 1879).

The genus Phylactocephalus was erected by Davis (1887) and put in synonymy with Halec by Woodward (1901). Goody (1969) verified marked differences between the genera and separated them. He re-erected Phylactocephalus with a single species, P. microlepis Davis, 1887.

Kner (1867) created the genus Hemisaurida containing a single species, H. neocomiensis. Woodward (1901) and Romer (1966) suggested that this genus could belong to the family Myctophidae. Goody (1969) rejected this hypothesis based mainly on two features present in halecoids: maxilla partially excluded from the mouth gape and premaxilla without ascending and articular processes. Yet, Goody (1969) created the species H. hakelensis.

\section{TAXA INCERTAE SEDIS}

Family Nardorexidae. The monotypic family Nardorexidae (Table V) was proposed by Taverne (2004) with the species Nardorex zorzini. He placed the family in the suborder Alepisauroidei based on putative relationships with Enchodontoidei.

Family Serrilepidae. The taxon was proposed by Chalifa (1989c) with the single species Serrilepis longidens. Forey et al. (2003) added two new species to the genus, S. prymnostrigos and S. minor. According to these authors, among the aulopiforms, Serrilepis is more closely related to Halec, Hemisaurida, and Phylactocephalus and, therefore, it should be classified into the Halecidae. This relationship is based on two synapomorphies: fusion of dorsal hypohyal and anterior ceratohyal; fusion of first and second hypurals and third and fourth hypurals. However, this latter synapomorphy is present in Atolvorator longipectoralis 
(Gallo and Coelho 2008), and we opted to use Chalifa's classification with Serrilepis in the family Serrilepidae (Table V).

Additionally, two other taxa, Yabrudichthys striatus Chalifa, $1989 \mathrm{c}$, and Atolvorator longipectoralis Gallo and Coelho, 2008, are considered Enchodontoidei incertae sedis and Cimolichthyoidei incertae sedis, respectively (Table V).

\section{MATERIALS AND METHODS}

\section{MATERIAL}

The specimens of Enchodontoidei herein studied belong to several paleontological collections (see Appendix I). Extant aulopiform, stomiiform, and myctophiform fishes were used as comparative specimens represented by dry skeletons, alcohol-preserved, and cleared and stained specimens. They belong to the AO.UERJ, O.UERJ, and MZUSP (see Appendix I). Moreover, for the taxa of difficult access, as for instance, those deposited in Hebrew University of Jerusalem and Museo Civico di Storia Naturale di Verona, we selected information from available literature (e.g., Chalifa 1985, 1989 a, b, c, 1996, Raab and Chalifa 1987, Taverne 2005a, b, 2006a, b).

\section{InSTITUTIONAL ABBREVIATIONS}

AO.UERJ, Ichthyological Collection, Instituto de Biologia, Universidade do Estado do Rio de Janeiro, Rio de Janeiro, Brazil; DGM, Divisão de Geologia e Mineralogia, Departamento Nacional da Produção Mineral, Rio de Janeiro, Brazil; FPH, Fundação Paleontológica Phoenix, Aracaju, Brazil; MN, Museu Nacional, Universidade Federal do Rio de Janeiro, Rio de Janeiro, Brazil; MNHN, Muséum National d'Histoire Naturelle, Paris, France; MZUSP, Museu de Zoologia, Universidade de São Paulo, São Paulo, Brazil; NHM, The Natural History Museum, London, England; O.UERJ, Ichthyological Collection, Instituto de Biologia, Universidade do Estado do Rio de Janeiro, Rio de Janeiro, Brazil; Pz.UERJ, Paleozoological Collection, Instituto de Biologia, Universidade do Estado do Rio de Janeiro, Rio de Janeiro, Brazil.

\section{Cladistic Methododology}

A data matrix was built with 87 characters, unordered and unweighted, 31 terminal taxa for ingroup, and three taxa for outgroup. The parsimony analysis was carried out using the computer program PAUP* version $4.0 \mathrm{~b} 10$ (Swofford 2001), with the heuristic algorithm HSearch. We tried to apply the exact branch-and-bound algorithm, but due to the length and complexity of the data matrix, we failed to obtain a result even running the analysis for a few days.

The character states that could not be verified mainly due to poor preservation were coded in the matrix as "?" (missing data). All characters previously proposed in the literature have been reviewed: the character 54 was adapted from Goody (1969); the characters $1,2,21,23,26,41,63,70,71,83$, and 84 were from Chalifa (1989a); the characters 3, 10, 11, 16, $19,24,25,29,30,33,38,42,64,65,77$, and 86 were from Taverne (1991); the characters 75,76 , and 81 were from Baldwin and Johnson (1996); the characters $5,6,7,17,31,48,49,50,52,57,62,66$, and 79 were from Fielitz (2004); the characters 4, 12, 14, $15,18,34,39,40,43,44,45,46,47,51,56,59,60$, $61,67,78,85$, and 87 were from Gallo et al. (2005). The new characters are $8,9,13,20,22,27,28,32$, $35,36,37,53,55,58,68,69,72,73,74,80$, and 82 . The terminal taxa for the ingroup were: Ichthyotringidae (Ichthyotringa), Apateopholidae (Apateodus, Apateopholis), Cimolichthyidae (Cimolichthys), Dercetidae (Apuliadercetis, Bentheskyme, Brazilodercetis, Caudadercetis, Cyranichthys, Dercetis, Dercetoides, Hastichthys, Nardodercetis, Ophidercetis, Pelargorhynchus, Robertichthys, Rhynchodercetis), Prionolepididae (Prionolepis), Enchodontidae (Rharbichthys, Palaeolycus, Eurypholis, Saurorhamphus, Enchodus, Parenchodus), Halecidae (Halec, Hemisaurida, Phylactocephalus), Serrilepidae (Serrilepis), as well as the incertae sedis genera Nardorex, Yabrudichthys, and Atolvorator. Outgroup is based on Protostomias (Stomiiformes), Trachinocephalus (Aulopiformes), and Sardinioides (Myctophiformes).

Appendix II includes the coded data matrix, which was built based on the list of characters presented in the Results. Only character states that resulted in apomorphies were illustrated. Although the strict consensus is the real consensus that shows all possible topologies, we opted to present the majority rule consensus (MRC) because, in general, it possesses a better resolution. The MRC is a form of consensus that pre- 


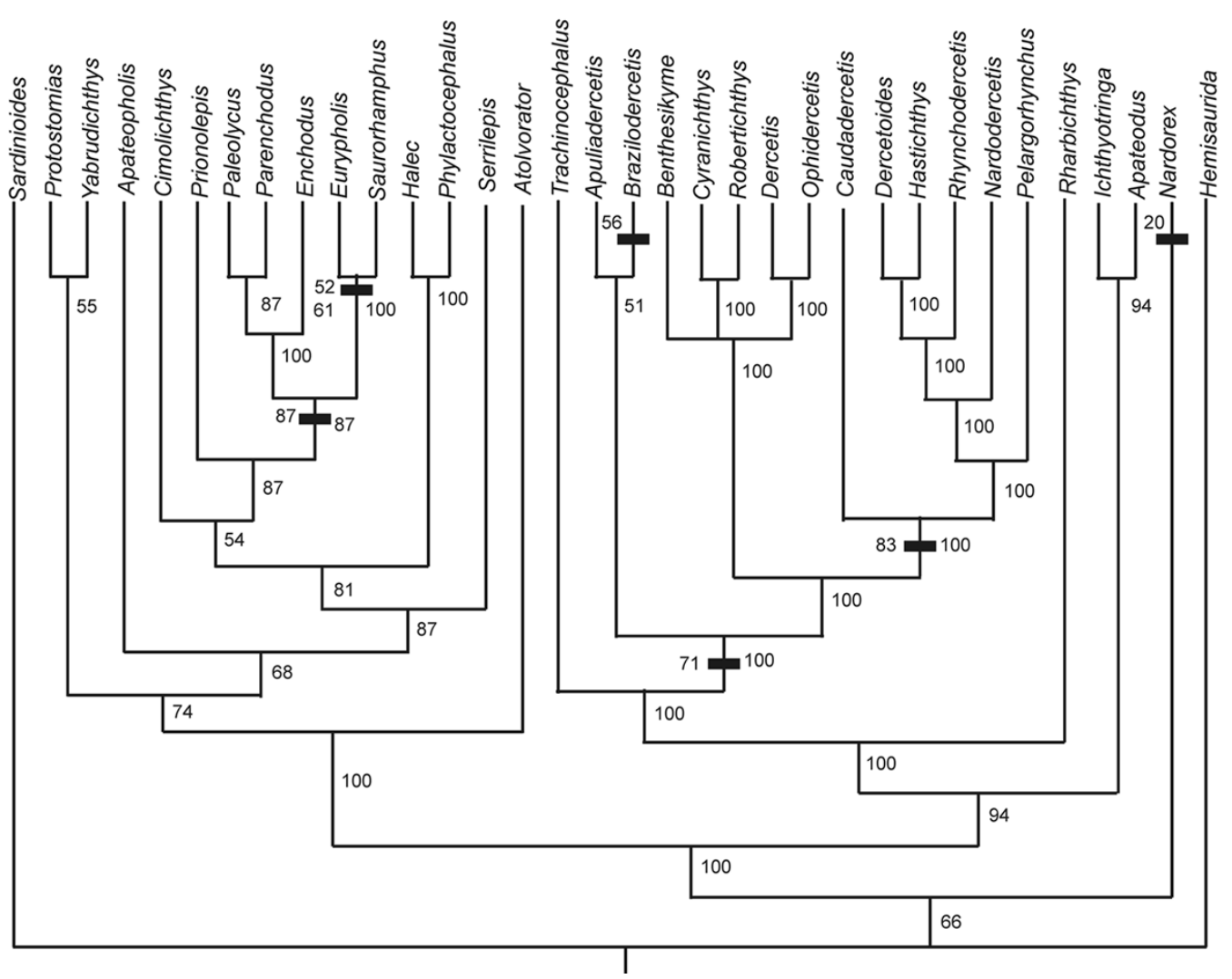

Fig. 1 - Majority rule consensus. Values represented at the right side in each branch indicate the percentage of the trees in which each clade is present. Numbers at the left side associated with a black bar indicate the characters that resulted in synapomorphies or autapomorphies.

serves all clades present in the majority (i.e., in more than $50 \%$ ) of the obtained set of equally parsimonious cladograms (Margush and McMorris 1981). The 50\% rule ensures that all included clades are compatible (Sharkey and Leathers 2001). In spite of some criticism (e.g., Sharkey and Leathers 2001), several authors are using MRC as a method of weighting clades to solve ambiguous strict consensus trees (e.g., Swofford 1991, Candall and Fritzpatrick 1996, Titus and Larson 1996, Lutzoni 1997).

\section{RESULTS}

Eighty-seven characters were analyzed in this study (see Appendix III). The cladistic analysis produced 93 equally parsimonious trees, with a tree length of 437 steps, consistency index (CI) of 0.24 , and retention index (RI) of 0.49 . The majority rule consensus tree is shown in Figure 1. The majority rule consensus tree is represented by the following topology: (Sardinioides
+ Hemisaurida + (Nardorex + (Atolvorator + (Protostomias + Yabrudichthys $)+$ (Apateopholis + $($ Serrilepis $+($ Halec + Phylactocephalus $)+($ Cimolichthys + (Prionolepis $+(($ Eurypholis + Saurorhamphus $)+($ Enchodus $+($ Paleolycus + Parenchodus $)))))))$ $+(($ Ichthyotringa + Apateodus $)+($ Rharbichthys $+($ Tra chinocephalus $+(($ Apuliadercetis + Brazilodercetis $)+$ (Benthesikyme + (Cyranichthys + Robertichthys $)+$ $($ Dercetis + Ophidercetis $))+$ (Caudadercetis + (Pelargorhynchus + (Nardodercetis + (Rhynchodercetis $+($ Dercetoides + Hastichthys $))))))$.

\section{DISCUSSION}

Before discussing the cladistic analysis per se, we will furnish a brief comment on certain characters.

According to Chalifa (1989a) and Taverne (1991), the presence of a low head is a synapomorphy of Dercetidae. In this study, it is shared with two other genera outside the group, showing a homoplastic distribution. 
In fossil aulopiform fishes, particularly in most of Cimolichthyoidei and Enchodontoidei (sensu Goody 1969), the snout length is equivalent to the diameter of the orbit (e.g., Cimolichthys and Eurypholis, respectively). All dercetids possess an elongate snout and the extreme condition is verified in Hastichthys, in which the snout length reaches more than 12 times the diameter of the orbit.

Fielitz (2004) considered the presence of vomerine teeth as a synapomorphy of the group formed by Cimolichthys and members of the family Enchodontidae. In the present study, this state of character has a homoplastic distribution, due to it is present in Nardorex and Prionolepis.

Gallo et al. (2005) interpreted the presence of a mesethmoid with a bifid anterior extremity as an autapomorphy of Dercetis, but herein this condition was also verified in Nardorex and Sardinioides. Yet, Gallo et al. (2005) pointed out a mesethmoid with a bifid posterior extremity in Dercetis. However, Taverne (2005b) described this bone with an acute posterior extremity, and we confirmed this feature in Dercetis elongatus (NHM P. 49793) and D. triqueter (MNHN SHA 523). Yet, Taverne (2006c) described Ichthyotringa africana as possessing a mesethmoid with acute posterior extremity, mainly based on specimens MNHN DTS 225-228. However, observing the specimen MNHN DTS 228, we verify a mesethmoid with bifid posterior extremity.

In Gallo et al. (2005), the autosphenotic spine posteriorly curved is a synapomorphy of the clade (Rhynchodercetis, Hastichthys). However, in this study, the character shows a slightly wide distribution, being also present in Atolvorator and Trachinocephalus. Taverne (2006b) stated that the autosphenotic of Caudadercetis is hidden by the frontals. For this reason, we opted to code it as missing data.

Accordig to Taverne (1991), Pelargorhynchus is characterized by four derived features, among them the loss of the supraoccipital crest. Gallo et al. (2005) considered the absence of the supraoccipital crest as an autapomorphy of Pelargorhynchus. In the present study, the character was differently interpreted, because its absence and/or loss were verified in other two taxa (Benthesikyme and Rharbichthys).
Gallo et al. (2005) pointed out the presence of a pterotic not projecting beyond the occiput in Dercetis based on available descriptions. However, we pointed out another condition (projecting beyond the occiput), following the redescription of the genus furnished by Taverne (2005b), as well as by direct observation of specimens of Dercetis triqueter and D. elongatus.

The presence of an unroofed post-temporal fossa in Palaeolycus followed Goody (1969), in contrast with Fielitz (2004) who pointed out a roofed condition. We verify a roofed condition in Eurypholis and Saurorhamphus in disagreement with Fielitz (2004). Gallo et al. (2005) pointed out a partially roofed posttemporal fossa in the genus Dercetis. However, following the redescription of the genus furnished by Taverne (2005b), as well as the direct observation of specimens of Dercetis triqueter and D. elongatus, we indicate herein a roofed post-temporal fossa to Dercetis.

Rosen (1973) pointed out the absence of orbitosphenoid in enchodontids. Additionally, Taverne (1991) stated that its absence would be a primitive condition of dercetids. Gallo et al. (2005) proposed the presence of orbitosphenoid as an autapomorphy of Ichthyotringa. Generally, the common absence of an orbitosphenoid in the specimens observed directly or indirectly is probably due to its fragility, which impedes a good preservation.

Gallo et al. (2005) suggested the presence of the basisphenoid as an autapomorphy of Ichthyotringa, but other taxa (i.e., Apuliadercetis tyleri, Atolvorator longipectoralis and Robertichthys riograndensis) bearing this bone were described after this study.

Taverne (1985) pointed out three conditions for the presence of teeth on the ectopterygoid: bone toothless or bearing some small conic teeth in a small portion of it as in Rharbichthys ferox, from the Cenomanian of Morocco; and well-developed teeth on the ectopterygoid similar to those found in the dentary of Rharbichthys cf. ferox from the Cenomanian-Turonian of Italy (see also Sorbini 1976). For this reason, the character was regarded as polymorphic.

In the cladistic analysis herein performed (Fig. 1), we demonstrate that the suborder Enchodontoidei is not a monophyletic group, as two genera of the outgroup belonging to another suborder and even to another order 

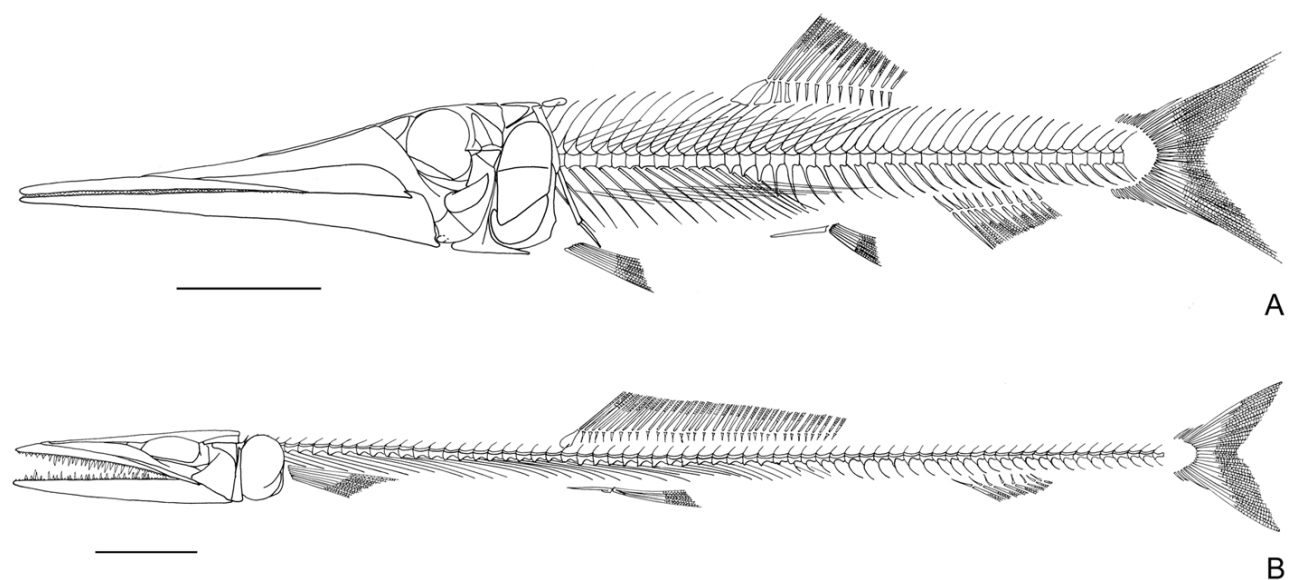

Fig. 2 - Neural spines. A, well-developed in Apateopholis laniatus (Davis, 1887), modified from Goody (1969); B, very reduced in Dercetis triqueter Pictet, 1850, modified from Goody (1969). Scale bars equal 20 mm.

(Trachinocephalus and Protostomias, respectively) went to the ingroup. Although Trachinocephalus belongs to the same order of the taxa herein studied (Aulopiformes), it is allocated into the suborder Synodontoidei, together with other extant members of Aulopiformes (Baldwin and Johnson 1996, Sato and Nakabo 2002). Arambourg (1954) and Taverne (1991) included Protostomias in the order Stomiifomes, based on generalized anatomical features, such as general shape of the body and a massive and tooth-bearing dentary, as well as the position of the median fins. Taverne (1992), in his comprehensive review of Protostomias, retained its placement in Stomiiformes.

Yet, the paraphyly of Enchodontoidei not allowed their taxonomic classification in the cladistic context.

The family Apateopholidae is not a monophyletic group, as Apateopholis is the sister-taxon of the clade including the family Enchodontidae (new usage) and the genera Cimolichthys, Prionolepis, Halec, Phylactocephalus, and Serrilepis. Apateodus, often placed with the Apateopholidae, is the sister-group of Ichthyotringa.

The monophyly of Dercetidae proposed by Gallo et al. (2005) and Blanco et al. (2008) was corroborated and supported by a single synapomorphy (very reduced neural spine; character 71) (Fig. 2), but the inclusion of new taxa changed the interrelationships of the family. The genus Apuliadercetis is the sister-group of Brazilodercetis and they are the basal clade of Dercetidae. Cyranichthys is the sister-taxon of Robertichthys, and
Dercetis is the sister-taxon of Ophidercetis. These two clades plus Benthesikyme form a new clade, which is an intermediary group between the basal and crown groups. However, the relationships within this intermediary group are uncertain. Caudadercetis appears as the most basal taxon in the major clade of Dercetidae (Caudadercetis, (Pelargorhynchus, (Nardodercetis, (Rhynchodercetis, (Hastichthys, Dercetoides)))). This clade is sustained by the unique presence of a convoluted suture marking the contact between second and third hypurals (character 83; Fig. 3B), although this character in Pelargorhynchus was coded as missing data, as its caudal skeleton is unknown. A pipe-shaped preopercle is an autapomorphy of Brazilodercetis (character 56; Fig. 4B).

Gallo et al. (2005) and Blanco et al. (2008) pointed out two synapomorphies of Dercetidae: the absence of a longitudinal opercular crest and a reduced neural spine. However, the absence of an opercular crest was also verified in other taxa. Yet, according to Gallo et al. (2005), Dercetoides is the sister-taxon of the clade formed by Rhynchodercetis and Hastichthys, but in Blanco et al. (2008) Dercetoides is the sister-taxon of Hastichthys, and both are sister-taxa of Rhynchodercetis. On the other hand, Taverne (2006b) stated that Dercetoides is the sister-taxon of Rhynchodercetis, and Hastichthys is the sister-taxon of the clade (Caudadercetis, (Pelargorhynchus, (Rhynchodercetis, Dercetoides))). Herein, 


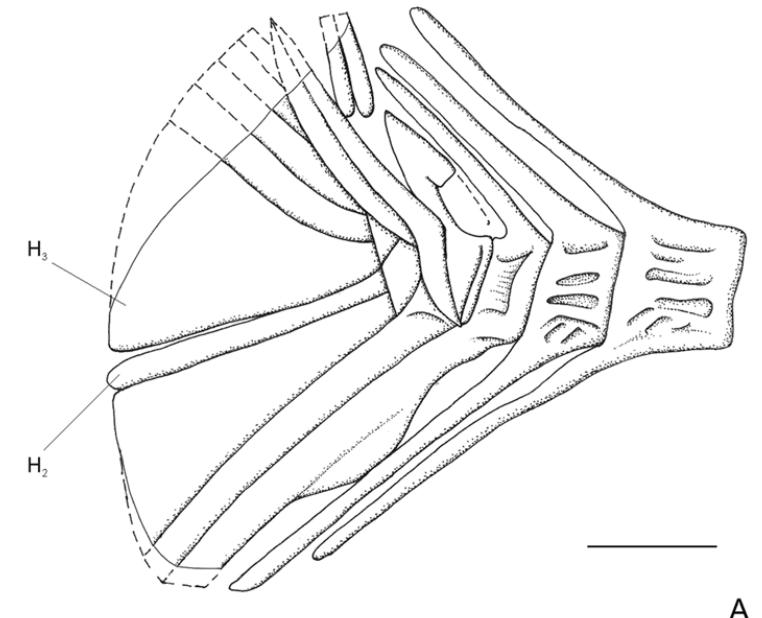

A

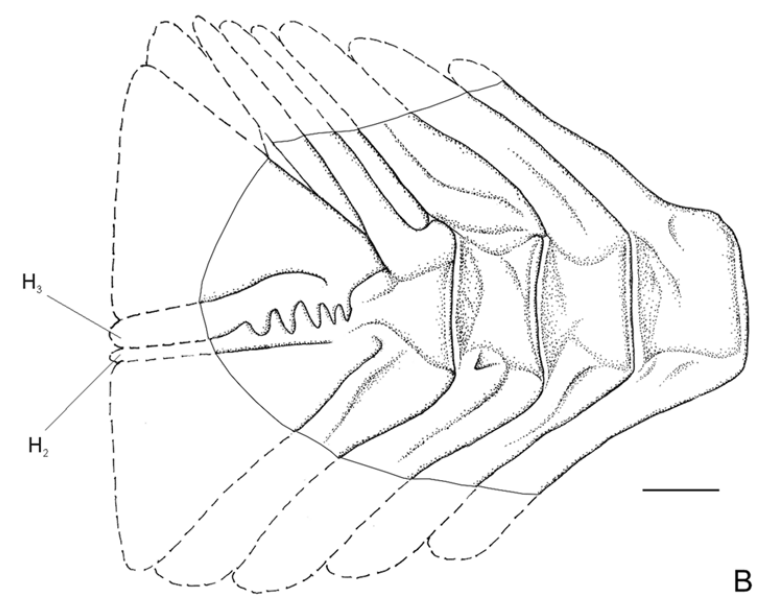

Fig. 3 - Contact between hypurals 2-3. A, free in Ichthyotringa furcata (Agassiz, 1844), modified from Goody (1969); B, convoluted suture in Hastichthys gracilis (Chalifa, 1989a), modified from Taverne (1991). Abbreviation: H, hypural. Scale bars equal $1 \mathrm{~mm}$.

Hastichthys appears as the sister-taxon of Dercetoides. Taverne (2006b) suggested Dercetis as the most basal dercetids, and Ophidercetis as the sister-taxon of Cyranichthys. However, we obtained different results: Dercetis forms a clade with Ophidercetis, and Cyranichthys is related to Robertichthys.

The family Enchodontidae is confirmed as monophyletic, as has already been proposed by Fielitz (2004), but herein it possesses a new composition. Parenchodus forms a clade with Palaeolycus, and Enchodus is the sister-group of this clade; the clade formed by (Eurypholis, Saurorhamphus) is the basal sister-group. Rharbichthys was excluded from the Enchodontidae, being recognized in this analysis as the sister-group of the clade formed by the Dercetidae plus the genus Trachinocephalus. Fielitz (2004) proposed three synapomorphies of Enchodontidae: the presence of a single dermopalatine tooth, dermopalatine bone with same length or shorter than the tooth, and the absence of an interopercle. In this analysis, these features were not corroborated as synapomorphies. For instance, a single tooth on the dermopalatine is also present in Ophidercetis, a genus of Dercetidae (Taverne 2005b). The remaining synapomorphy of this family is the presence of middorsal scutes (character 87; Fig. 5). In addition, the clade (Eurypholis, Saurorhamphus) is supported by two synapomorphies: quadrate-mandibular articulation hidden (character 52; Fig. 6) and the presence of a spine on posterior border of the opercle (character 61; Fig. 7).

Halecidae possess a new composition: Halec is the sister-group of Phylactocephalus; and Hemisaurida was excluded from the family, being considered Aulopiformes incertae sedis, like Nardorex.

The presence of a well-developed supraoccipital divided into two distinct regions is an autapomorphy of Nardorex (character 20; Fig. 8B). These two regions are separated by a slight transverse ridge: the anterior region is reduced and contacts the parietals, whereas the posterior one is large, contacts the epioccipitals and bears a high median crest (Fig. 8B).

\section{ACKNOWLEDGMENTS}

We are most grateful to R.C.T. Cassab (Departamento Nacional de Produção Mineral, Rio de Janeiro), D.D.R. Henriques (Museu Nacional/Universidade Federal do Rio de Janeiro, Rio de Janeiro), O.T. Oyakawa (Museu de Zoologia/Universidade de São Paulo, São Paulo), M. Richter (The Natural History Museum, London), H.R.S. Santos (Universidade do Estado do Rio de Janeiro, Rio de Janeiro), W. Souza-Lima (Fundação Paleontológica Phoenix, Aracaju), and M. Véran (Muséum National d'Histoire Naturelle, Paris), for access to specimens in their care. We thank S.A. Azevedo, M.J. Cavalcanti, F.J. de Figueiredo, and J. Alvarado Ortega for critical comments to the M.S. thesis of the H.M.A.S advised by V.G., on which this paper is based. We are particularly grateful to T. Moulton for his help with the 

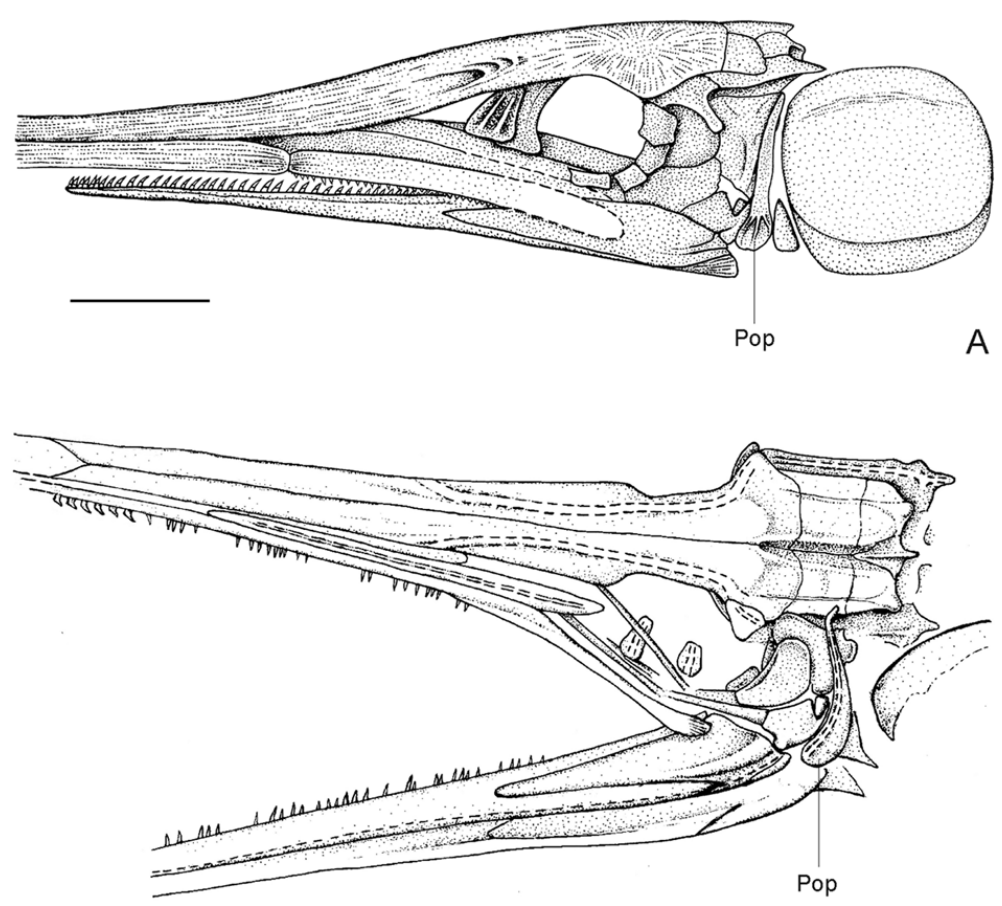

B

Fig. 4 - Preopercle shape. A, triangular in Hastichthys gracilis (Chalifa, 1989a), modified from Taverne (1991); B, pipe-shaped in Brazilodercetis longirostris Figueiredo and Gallo, 2006, modified from Figueiredo and Gallo (2006). Abbreviation: Pop, preopercle. Scale bars equal $10 \mathrm{~mm}$.
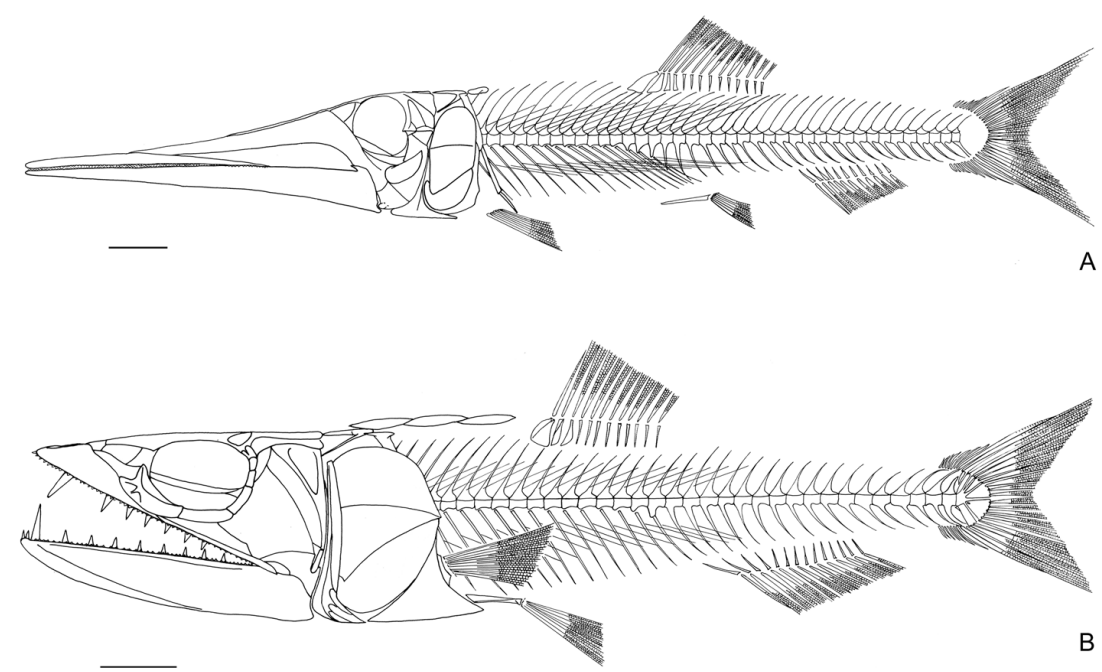

Fig. 5 - Middorsal scutes. A, absent in Apateopholis laniatus (Davis, 1887), modified from Goody (1969); B, present in Eurypholis boissieri Pictet, 1850, modified from Goody (1969). Scale bars equal $10 \mathrm{~mm}$. 

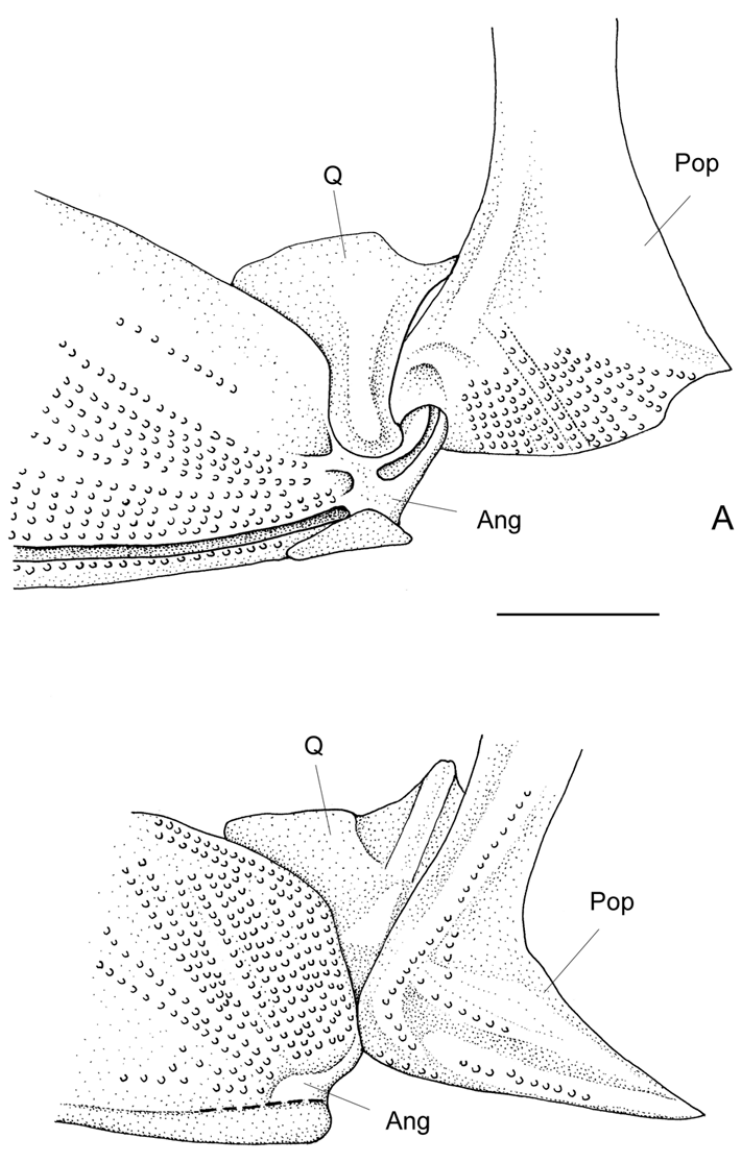

B

Fig. 6 - Quadrate-mandibular articulation. A, exposed in Enchodus marchesettii, modified from Fielitz (2004); B, hidden in Eurypholis boissieri Pictet, 1850, modified from Fielitz (2004).

Abbreviations: Ang, angular; Pop, preopercle; $\mathbf{Q}$, quadrate. Scale bars equal $3 \mathrm{~mm}$.

English revision. This research was part of a Project supported by the Conselho Nacional de Desenvolvimento Científico e Tecnológico (CNPq 476708/2004-4) and the Fundação Carlos Chagas de Amparo à Pesquisa do Estado do Rio de Janeiro (FAPERJ E-26/171.215/2004). HMAS holds a fellowship from the FAPERJ and VG has research fellowship grants from the CNPq (Brazilian Federal Government), from the FAPERJ (Jovem Cientista do Nosso Estado), and from the PROCIÊNCIA (Rio de Janeiro State Government).

\section{RESUMO}

Os Enchodontoidei são peixes teleósteos marinhos extintos, com uma longa amplitude temporal e uma ampla distribuição geográfica. Tendo em vista que não há nenhuma proposta ampla para a filogenia deste táxon, foi realizada uma análise de parcimônia com base numa matriz de dados de 87 caracteres, 31 táxons terminais no grupo interno, e três táxons no grupo externo. Como resultado da análise, foram obtidas 93 árvores igualmente parcimoniosas $(\mathrm{L}=437$ passos; CI $=0,24 ; \mathrm{RI}=0,49)$. O consenso de maioria é representado pela seguinte topologia: (Sardinioides + Hemisaurida + (Nardorex $+($ Atolvorator + (Protostomias + Yabrudichthys $)$ $+($ Apateopholis $+($ Serrilepis $+($ Halec + Phylactocephalus $)$ $+($ Cimolichthys $+($ Prionolepis $+(($ Eurypholis + Saurorhamphus $)+($ Enchodus $+($ Paleolycus + Parenchodus $)))))))+$ $(($ Ichthyotringa + Apateodus $)+($ Rharbichthys + (Trachinocephalus $+(($ Apuliadercetis + Brazilodercetis $)+($ Benthesikyme $+($ Cyranichthys + Robertichthys $)+($ Dercetis + Ophidercetis $))$ + (Caudadercetis + (Pelargorhynchus + (Nardodercetis + $($ Rhynchodercetis $+($ Dercetoides + Hastichthys $))))))$. O grupo 


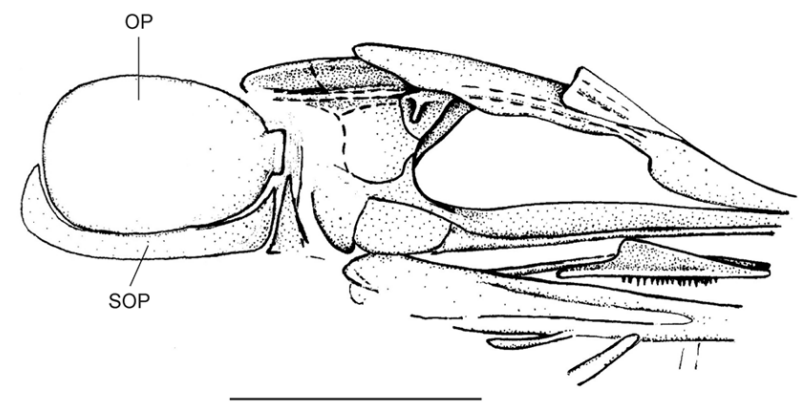

A

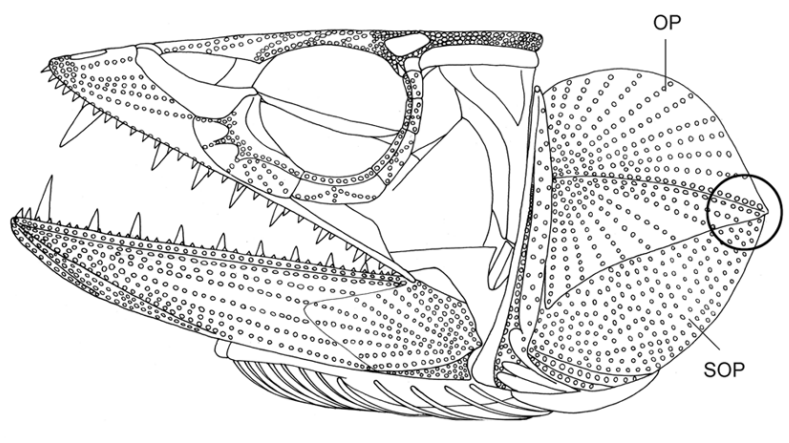

B

Fig. 7 - Spine on posterior border of the opercle. A, absent in Brazilodercetis longirostris Figueiredo and Gallo, 2006, modified from Figueiredo and Gallo (2006); B, present in Eurypholis boissieri Pictet, 1850, modified from Goody (1969), delimited by a circle. Abbreviations: Op, opercle; Sop, subopercle. Scale bars equal $10 \mathrm{~mm}$.
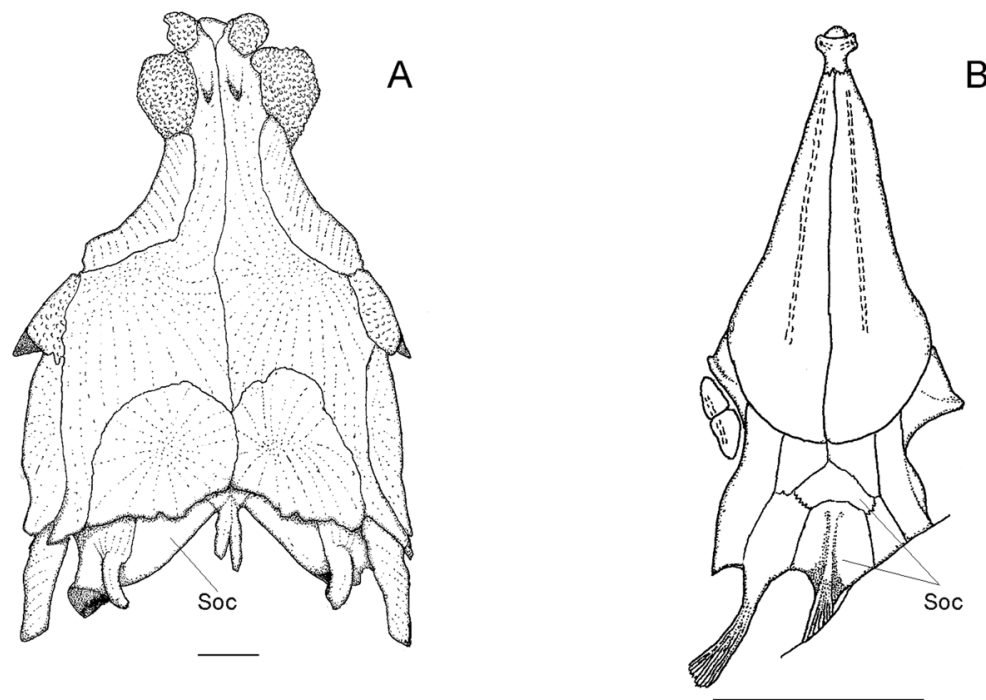

Fig. 8 - Supraoccipital with two well-delimited regions. A, absent in Trachinocephalus myops (Forster, 1801) (based on the specimen AO.UERJ 17); B, present in Nardorex zorzini Taverne, 2004 (modified from Taverne 2004). Abbreviation: Soc, supraoccipital. Scale bars equal $30 \mathrm{~mm}$. 
Enchodontoidei não é monofilético. Os Dercetidae formam um clado suportado pela presença de espinhos neurais muito reduzidos e possuem uma nova composição. Os Enchodontidae são um grupo monofilético, devido à presença de escudos no dorso, e Rharbichthys foi excluído do clado. Os Halecidae possuem uma nova composição, com a exclusão de Hemisaurida. Este táxon e Nardorex são Aulopiformes incertae sedis.

Palavras-chave: Aulopiformes, Enchodontoidei, filogenia, taxonomia.

\section{REFERENCES}

AgAssiz L. 1833-1844. Recherches sur les Poissons Fossiles, Ed. Petitpierre, t. 1-5. Neuchatel, 1420 p.

AgASSiz L. 1834. Abgerissene Bemerkungen übber fossile Fische. Neues Jahrb Miner Geog Geol Petr 4: 379-390.

ArAmbourg C. 1943. Note préliminaire sur quelques poissons fossiles nouveaux. B Soc Geol Fr 8: 281-285.

Arambourg C. 1952. Les vertébrés fossiles des gisements de phosphates (Maroc-Algérie-Tunisie). Notes Mem Serv geol Maroc 92: 1-372.

Arambourg C. 1954. Les poissons crétacés du Jebel Tselfat (Maroc). Notes Mem Serv geol Maroc 118: 1-188.

BALDWIN CC AND JOHNSON GD. 1996. Interrelationships of Aulopiformes. In: StIASSNy MLJ, PAREnTI LR AND JOHNSON GD (Eds), Interrelationships of Fishes, San Diego: Academic Press, p. 335-404.

Bardet N, Cappetta H, Pereda Suberbiola X, Mouty M, al Maleh AKA, Ahmad M, Khrata O And GANNOUM N. 2000. The marine vertebrate faunas from the Late Cretaceous phosphates of Syria. Geol Mag 137: 269-290.

Bardet N and Pereda Suberbiola X. 2002. Marine reptiles from the Late Cretaceous Phosphates of Jordan: palaeobiogeographical implications. Geodiversitas 24: 831-839.

BERG LS. 1937/1940. Classification of Fishes Both Recent and Fossil, J.W. Edwards (1947), Michigan: Ann Arbor, 517 p. [Russian and English].

Bertin L AND ARAmbourg C. 1958. Super-ordre des Téléostéens. In: GRASSÉ P-P (Ed), Traité de Zoologie, 13, Paris: Masson et Cie, p. 2204-2500.

Blanco A and Alvarado-Ortega J. 2006. Rhynchodercetis regio, sp. nov., a dercetid fish (Teleostei: Aulopiformes) from Vallecillo, Nuevo León State, Northeastern Mexico. J Vertebr Paleontol 26: 552-558.
Blanco A, Alvarado-Ortega J And Gallo V. 2008. Robertichthys riograndensis from the Lower Turonian (Upper Cretaceous) Vallecillo Lagerstätte, NEMexico: Description and relationships. In: ArRATIA G, Schultze H-P AND Wilson MVH (Eds), Mesozoic Fishes 4 - Homology and Phylogeny, München: Verlag Dr. Friedrich Pfeil, p. 389-397.

Blanco-Pinõn A And Alvarado-Ortega J. 2005. New dercetid fish (Aulopiformes: Teleostei) from the Early Turonian of Vallecillo, NE Mexico. In: POYATO-ARIZA FJ (Ed), Extended Abstracts of the $4^{\text {th }}$ Internacional Meeting on Mesozoic Fishes - Systematics, Homology, and Nomenclature, Miraflores de la Sierra, Madrid: Ediciones Universidad Autónoma de Madrid, p. 43-46.

Breton G, Bilotte M And Sigro G. 1995. Dipsacaster jadeti sp. nov., Astropectinidae (Asteroidea, Echinodermata) du Maastrichtien des Petites Pyrénées (France). Bull Soc Geol de Normandie et des Amis du Muséum 82: $35-42$.

CANDALl KA AND FRITZPATRICK JF JR. 1996. Crayfish molecular systematics: Using a combination of procedures to estimate phylogeny. Syst Biol 45: 1-26.

CAVIN L. 1999. Occurrence of a juvenile teleost, Enchodus sp., in a fish gut content from the Upper Cretaceous Goulmima, Morocco. Spec Pap Palaeontol 60: 57-72.

CAVIN L AND Dutheil DB. 1999. A new Cenomanian ichthyofauna from southeastern Morocco and its relationships with other early Late Cretaceous Morrocan faunas. Geol Mijnbouw 78: 261-266.

CAVIn L, Jurkovsek B And Kolar-JurkovseK T. 2000. Stratigraphic succession of the Upper Cretaceous fish assemblages of Kras (Slovenia). Geologija 43: 165-195.

Chalifa Y. 1985. Saurorhamphus judeaensis (Salmoniformes: Enchodontidae), a new longirostrine fish from the Cretaceous (Cenomaniam) of Ein-Yabrud, near Jerusalem. J Vertebr Paleontol 5: 181-193.

Chalifa Y. 1989a. Two new species of longirostrine fishes from the Early Cenomanian (Cretaceous) of Ein-Yabrud, Israel, with comments on the phylogeny of the Dercetidae. J Vertebr Paleontol 9: 314-328.

Chalifa Y. 1989b. New species of Enchodus (Pisces: Enchodontoidei) from the Lower Cenomanian of Ein-Yabrud, Israel. J Paleontol 63: 356-364.

Chalifa Y. 1989c. Yabrudichthys and Serrilepis, two new genera of enchodontoids (Teleostei) from Lower Cenomanian beds of Ein-Yabrud, Israel. Israel J Zool 36: 11-38.

CHALIFA Y. 1996. New species of Enchodus (Aulopiformes: Enchodontidae) from the Northern Negev, Israel, with comments on evolutionary trends in the Enchodontoidei. 
In: Arratia G And Schultze H-P (Eds), Mesozoic Fishes 1 - Systematics and Paleoecology, München: Verlag Dr. Friedrich Pfeil, p. 349-367.

Coelho PM. 2004. Revisão sistemática dos †Enchodontidae (Euteleostei: Aulopiformes) do Brasil. M.S. Thesis, Museu Nacional/Universidade Federal do Rio de Janeiro, Rio de Janeiro, 83 p. (Unpublished).

COPE ED. 1872. On the families of fishes of the Cretaceous Formation of Kansas. P Am Philos Soc 12: 327-357.

COPE ED. 1874. Review of the Vertebrata of the Cretaceous period found West of the Mississippi River. B United States Geol Geog Survey of the Territories 1: 5-48.

Cope ED. 1878. Description of fishes from the Cretaceous and Tertiary deposits West of the Mississippi River. B United States Geol Geog Survey of the Territories 4: 6777.

CRipps JA, WidDowson M, SPICER RA AND JOLlEy DW. 2005. Coastal ecosystem responses to late stage Deccan Trap volcanism: the post K-T boundary (Danian) palynofacies of Mumbai (Bombay), west India. Palaeogeogr Palaeocl Palaeoecol 216: 303-332.

DAVIS JW. 1887. The fossil fishes of the Chalk of Mount Lebanon in Syria. Sci T Roy Dublin Soc 3: 457-636.

DAVIS JW. 1890. On the fossil fish of Cretaceous formation of Scandinavia. Sci T Roy Dublin Soc 4: 363-434.

D’Erasmo G. 1912. II Saurorhamphus freyeri Heckel degli scisti bituminosi cretacei del Carso Triestino (Comen, Malidol e Vucigrad). Boll Soc Adriat Sci Nat Trieste 26: $45-88$.

DiXON F. 1850. The Geology and Fossils of the Tertiary and Cretaceous Formations of Sussex. London: R \& J Taylor, $422 \mathrm{p}$.

FiElitz C. 1996. A Late Cretaceous (Turonian) ichthyofauna from Lac des Bois, Northwest Territories, Canada, with paleobiogeographic comparisons with Turonian ichthyofaunas of the Western Interior Seaway. Can J Earth Sci 33: 1375-1389.

FIELITZ C. 2004. The phylogenetic relationships of the $\dagger$ Enchodontidae (Teleostei: Aulopiformes). In: ARRATIA G, Wilson MVH AND Cloutier R (Eds), Recent Advances in the Origin and Early Radiation of Vertebrates, München: Verlag Dr. Friedrich Pfeil, p. 619-634.

Fielitz C And GonzÁlez RodríGUEz K. 2008. A new species of Ichthyotringa from the El Doctor Formation (Cretaceous), Hidalgo, Mexico. In: Arratia G, SChultze H-P AND Wilson MVH (Eds), Mesozoic
Fishes 4 - Homology and Phylogeny, München: Verlag Dr. Friedrich Pfeil, p. 373-388.

FiElitz C AND ShimadA K. 2009. A new species of Apateodus (Teleostei: Aulopiformes) from the Upper Cretaceous Niobrara Chalk of western Kansas, U.S.A. J Vertebr Paleontol 29: 650-658.

Figueiredo FJ And Gallo V. 2006. A new dercetid fish (Neoteleostei: Aulopiformes) from the Turonian of the Pelotas basin, southern Brazil. Palaeontology 49: 445456.

Figueiredo FJ, Gallo V and Coelho PM. 2001. First occurrence of Rharbichthys (Teleostei: Enchodontidae) in the Upper Cretaceous of Pelotas Basin (Atlântida Formation), Southern Brazil. Bol Mus Nac NS Geol 61: 1-8.

Forey PL, Yi L, Patterson C And Davies CE. 2003. Fossil fishes from the Cenomanian (Upper Cretaceous) of Namoura, Lebanon. J Syst Palaeontol 1: 227-330.

Frickhinger KA. 1995. Fossil Atlas, Fishes, Mergus, Publishers for Natural History and Pet Books. Melle: Hans A. Baensch, 1088 p.

Gallo-DA-Silva V. 1993. A "Coleção Cope" do Museu Nacional/UFRJ: Vertebrados Fósseis da Bahia, Sergipe e Pernambuco (Brasil), e sua Correlação Estratigráfica. M.S. Thesis, Instituto de Geociências/Universidade Federal do Rio de Janeiro, Rio de Janeiro, 130 p. (Unpublished).

Gallo V and Coelho PM. 2008. First occurrence of an aulopiform fish in the Barremian of the SergipeAlagoas Basin, northeastern Brazil. In: ARratia G, Schultze H-P AND Wilson MVH (Eds), Mesozoic Fishes 4 - Homology and Phylogeny, München: Verlag Dr. Friedrich Pfeil, p. 351-371.

Gallo V, Figueiredo FJ And Coelho PM. 2006. Paleoictiofauna da Formação Atlântida, Cretáceo Superior da Bacia de Pelotas, sul do Brasil. In: Gallo V, BRito PM, Silva HMA And Figueiredo FJ (Eds), Paleontologia de Vertebrados: Grandes Temas e Contribuições Científicas, Rio de Janeiro: Interciência, p. 113-131.

Gallo V, Figueiredo FJ And Silva HMA. 2005. Análise filogenética dos Dercetidae (Teleostei: Aulopiformes). Arq Mus Nac 63: 329-352.

Gayet M. 1991. Holostean and teleostean fishes from Bolivia. In: SuÁrez-Soruco R (Ed), Fósiles y Facies de Bolivia, I. Revista Técnica de YPFB 12: 453-494.

Goody PC. 1968. The skull of Enchodus faujasi from the Maastricht of Southern Holland. PK Ned Akad B Phys 71: 209-231. 
Goody PC. 1969. The relationships of certain Upper Cretaceous teleosts with special reference to the myctophoids. Bull Brit Mus (Nat Hist) Geol Supp 7: 1-255.

Goody PC. 1970. The Cretaceous teleostean fish Cimolichthys from the Niobrara Formation of Kansas and the Pierre Shale of Wyoming. Am Mus Novitates 2434: $1-29$.

Goody PC. 1976. Enchodus (Teleostei: Enchodontidae) from the Upper Cretaceous Pierre Shale of Wyoming and South Dakota with an evaluation of the North American enchodontid species. Palaeont Abh A 152: 91-112.

GREGORY WK. 1933. Fish skulls: a study of the evolution of natural mechanism. T Am Philos Soc 23: 1-481.

HAY OP. 1903. On a collection of Upper Cretaceous fishes from Mount Lebanon, Syria, with description of four new genera and nineteen new species. B Am Mus Nat Hist 19: 395-452.

HeCKel J. 1850. Beiträge zur Kenntniss der fossilen Fische Österreichs. Denkschr kais Akad Wiss math-naturwiss 1: 201-242.

Jacobs Ll, Mateus O, Polcyn MJ, Schulp AS, AnTUNes MT, Moraos ML AND TAVAREs TS. 2006. The occurrence and geological setting of Cretaceous dinosaurs, mosasaurs, plesiosaurs, and turtles from Angola. J Paleontol Soc Korea 22: 91-110.

Jaillard E, Cappetta H, Ellenberger P, Feist M, Grambast-Fessard N, LeFranc JP AND Sigé B. 1993. Sedimentology, paleontology, bioestratigraphy and correlation of the Late Cretaceous Vilquechico group of southern Peru. Cretaceous Res 14: 623-661.

JORDAN DS. 1905. A Guide to the Study of Fishes, Henry Holt and Company, vol. 2. New York, 544 p.

KADDUMi HF. 2006. A new genus and species of gigantic marine turtles (Chelonioidea: Cheloniidae) from the Maastrichtian of the Harrana Fauna-Jordan. PalArch's J Vert Palaeontol 3: 1-14.

KNER R. 1867. Neuer Beitrag zur Kenntniss der fossilen Fische von Comen bei Goerz. Sitz Kais Akad Wiss MathNaturwiss Class 56: 171-200.

Kriwet J AND Gloy U. 1995. Zwei mesopelagische Raubfische (Actinopterygii: Euteleostei) aus dem Unterturon der Kronsberg-Mulde bei Hannover/Misburg (NWDeutschland). Berliner Geowiss Abh E 16: 335-355.

KruizingA P. 1924. Apateodus corneti (For) in the Senonian beds of the southern part of Limburg (Netherland). PK Ned Akadn Wetensc 27: 293-312.
LEIDY J. 1857. Remarks on Saurocephalus and its allies. P Acad Nat Sci Phila 8: 301-302.

LEONARDI A. 1966. L'ittiofauna cenomaniana di FlorestaMessina. Palaeontol Ital 60: 33-67.

LERICHE M. 1902. Revision de la faune ichthyologique des terrains Crétacés du Nord de la France. Ann Soc Geol Nord 31: 87-155.

LERICHE M. 1906. Contribution a l'etude des poissons fossiles du nord de la France et des régions voisines. Mem Soc Geol Nord 5: 1-430.

LundGREN B. 1889. Om kritfaunan vid Tormarp i Halland och de halländska kritbildningarnes förhiållande till öfriga svenska. Geol Fören Stock För 11: 63-72.

LUtZONi FM. 1997. Phylogeny of lichen- and non lichenforming omphalinoid mushrooms and the utility of testing for combinability among multiple data sets. Syst Biol 46: 373-406.

MARCK W VON DER. 1858. Über einige Wirbeltiere, Kruster und Cephalopoden der Westfälischen Kreide. Z Dtsch Geol Ges 10: 231-271.

MARCK W VON DER. 1863. Fossile Fische, Krebse und Pflanzen aus dem Plattenkalk der jüngsten Kreide aus Westphalen. Palaeontographica 11: 1-83.

Margush T AND MCMORRIS FR. 1981. Consensus ntrees. Bull math Biol 43: 239-244.

Murray AM. 2000. The Palaeozoic, Mesozoic and Early Cenozoic fishes of Africa. Fish and Fisheries 1: 111-145.

NELSON JS. 1994. Fishes of the World, $3^{\text {rd }}$ ed., New York: J Wiley and Sons, Inc., $600 \mathrm{p}$.

NELSON JS. 2006. Fishes of the World, $4^{\text {th }}$ ed., New Jersey: J Wiley and Sons, Inc., $601 \mathrm{p}$.

PiCtet FJ. 1850. Description de quelques Poissons Fossiles du Mont Liban, Genève: J.-G. Fick, 59 p.

Pictet FJ AND HumberT A. 1866. Nouvelles recherches sur les poissons fossiles du Mont Liban, Genève: Georg, $114 \mathrm{p}$.

RaAB M AND Chalifa Y. 1987. A new enchodontid fish genus from the Upper Cenomanian of Jerusalem, Israel. Palaeontology 30: 717-731.

Rana RS, Kumar K, Singh H And Rose KD. 2005. Lower vertebrates from the Late Palaeocene-Earliest Eocene Akli Formation, Giral Lignite Mine, Barmer District, Western India. Curr Sci India 89: 1606-1613.

Rebouças JC And Silva Santos R. 1956. Fauna ictiológica do fosfato de Pernambuco. Bol DNPM/DGM 162: $1-29$. 
REGAN CT. 1911. The anatomy and classification of the teleostean fishes of the order Iniomi. Ann Mag Nat Hist 7: $120-133$.

Rigo D. 1999. The fossils of the Cretaceous Lagerstätte of Polazzo (Fogliano-Rediplugia, Gorizia, NE Italy). Natura Nascota 19: 10-19.

Romer AS. 1945. Vertebrate Paleontology, $2^{\text {nd }}$ ed., Chicago: University of Chicago Press, 687 p.

Romer AS. 1966. Vertebrate Paleontology, 3rd ed., Chicago: University of Chicago Press, 468 p.

Rosen DE. 1973. Interrelationships of higher euteleostean fishes. In: GreEnwood PH, Miles RS AND PATterSON C (Eds), Interrelationships of Fishes, Zoological Journal of the Linnean Society, Supplement 1, London, p. 397-513.

Sato T And Nakabo T. 2002. Paraulopidae and Paraulopus, a new family and genus of aulopiform fishes with revised relationships within the order. Ichth Res 49: 25-46.

SHARKEY MJ AND LEATHERS JW. 2001. Majority does not rule: the trouble with majority-rule consensus trees. Cladistics 17: 282-284.

SiEgfried P. 1954. Die Fisch-Fauna des Westfälischen OberSenons. Palaeont Abh A 106(1-2): 1-36.

Siegfried P. 1966. Zur Osteologie der Gattung Dercetis Agassiz (Teleostei, Pisces). Paläont Zeitsch 40: 205-217.

Silva HMA AND GALlo V. 2007. Cladistic analysis of the Enchodontoidei (Teleostei: Aulopiformes). J Vertebr Paleontol 27(Suppl. 3): 65A.

Silva Santos R And Salgado MS. 1969. Enchodus longipectoralis (Schaeffer), um Teleostei do Cretáceo Superior de Sergipe. An Acad Bras Cienc 41: 381-392.

Sorbini L. 1976. L'ittiofauna cretacea di Cinto Euganeo (Padova - Nord Italia). Boll Mus Civ Stor Nat Verona 3: 469-567.

SWOFFORD DL. 1991. When are phylogeny estimates from molecular and morphological data incongruent? In: Miyamoto MM AND CRACRAft J (Eds), Phylogenetic analysis of DNA sequences, New York: Oxford University Press, p. 295-333.

SWOFFORD DL. 2001. PAUP* 4.0b8a, Massachusetts: Sinauer Associates, Sunderland.

TAVERne L. 1985. Les Aulopiformes (Pisces, Teleostei) du Crétacé supérier de la Mésogée eurafricaine. I. Ostéologie et affinités systématiques de Rharbichthys Arambourg, C. 1954. Acad Roy Belg Bull Cl Sci 5e ser 71: 26-46.
TAVERNE L. 1987. Ostéologie de Cyranichthys ornatissimus nov. gen. du Cénomanien du Zaïre et de Rhynchodercetis yovanovitchi du Cénomanien de l'Afrique du Nord. Les relations intergénériques et la position systématique de la famille néocrétacique marine des Dercetidae (Pisces, Teleostei). Ann Mus Roy Afr Centr Rapp Ann 19851986: 93-112.

TAVERnE L. 1991. New considerations on the osteology and phylogeny of the Cretaceous marine teleost family Dercetidae. Biol Jaarb Dodonaea 58: 94-112.

TAVERne L. 1992. Révision du genre Protostomias, téléostéen Stomiiforme crétacique de la Mésogée eurafricaine. Biol Jaarb Dodonaea 59: 57-76.

TAVERNE L. 2004. Les poissons crétacés de Nardò. $19^{\circ}$ Nardorex zorzini gen. et sp. nov. (Teleostei, Aulopiformes, Alepisauroidei). Boll Mus Civ Stor Nat Verona Geol Paleonto Preist 28: 29-40.

TAVERnE L. 2005a. Les poissons crétacés de Nardò. $22^{\circ}$ Nardodercetis vandewallei gen. et sp. nov. (Teleostei, Aulopiformes, Dercetidae). Boll Mus Civ Stor Nat Verona Geol Paleonto Preist 29: 81-93.

TAVERnE L. 2005b. Les poissons crétacés de Nardò. $21^{\circ}$ Ophidercetis italiensis gen. et sp. nov. (Teleostei, Aulopiformes, Dercetidae). Une solution ostéologique au problème des genres Dercetis et Benthesikyme (=Leptotrachelus). Boll Mus Civ Stor Nat Verona Geol Paleonto Preist 29: 55-79.

TAVerne L. 2006a. Les poissons crétacés de Nardò. $23^{\circ}$ Apuliadercetis tyleri gen. et sp. nov. (Teleostei, Aulopiformes, Dercetidae). Boll Mus Civ Stor Nat Verona Geol Paleonto Preist 30: 11-26.

TAVERnE L. 2006b. Les poissons crétacés de Nardò. $24^{\circ}$ Caudadercetis bannikovi gen. et sp. nov. (Teleostei, Aulopiformes, Dercetidae). Considérations sur la phylogénie des Dercetidae. Boll Mus Civ Stor Nat Verona Geol Paleonto Preist 30: 27-48.

TAVERNE L. 2006c. Révision d'Ichthyotringa africana, poisson marin (Teleostei, Aulopiformes) du Crétacé supérier de la Mésogée eurafricaine. Considérations sur les relations phylogénétiques du genre Ichthyotringa. Belg J Zool 136: 31-41.

TAVERNE L. 2008. Les poissons crétacés de Nardò. $27^{\circ}$ Leccedercetis longirostris gen. et sp. nov. (Teleostei, Aulopiformes, Dercetidae). Boll Mus Civ Stor Nat Verona Geol Paleonto Preist 32: 3-8.

Titus TA AND LARSON A. 1996. Molecular phylogenetics of desmognathine salamanders (Caudata: Plethodonti- 
dae): A reevaluation of evolution in ecology, life history, and morphology. Syst Biol 45: 451-472.

White EI AND Moy-Thomas JA. 1940. Notes on the nomenclature of fossil fishes. Part II. Homonyms D-L. Ann Mag Nat Hist 6: 98-103.

Wilson MVH AND CHALIFA Y. 1989. Fossil marine actinopterygian fishes from the Kaskapau Formation (Upper Cretaceous: Turonian) near Watino, Alberta. Can J Earth Sci 26: 2604-2620.

WOODWARD AS. 1888. A comparison of the Cretaceous fish fauna of Mount Lebanon with that of the English Chalk. Ann Mag Nat Hist 6: 354-355.

WoOdWARD AS. 1891. On some Upper Cretaceous fishes of the family Aspidorhynchidae. Proc Zool Soc London 1890: 629-637.

Woodward AS. 1901. Catalogue of the Fossil Fishes in the British Museum (Natural History). Part IV. British Museum (Natural History). London: xxxviii +636 p.

YABUmoto Y And Uyeno T. 1994. Late Mesozoic and Cenozoic fish faunas of Japan. Island Arc 3: 255-269.

\section{APPENDIX I \\ List of the analyzed material}

RECENT MATERIAL

Synodontidae - Trachinocephalus myops: AO.UERJ 17; AO.UERJ 123; AO.UERJ 127; AO.UERJ 128; O.UERJ 471; O.UERJ 1334; O.UERJ 2073.

Evermannellidae - Coccorella atlantica: MZUSP 78193.

Paralepididae - Lestidium atlanticum: MZUSP 60327; Lestrolepis intermedia: MZUSP 80717.

\section{FOSSIL MATERIAL}

Enchodontidae - Enchodus sp. 1: Pz.UERJ 489; Pz.UERJ 490; Pz.UERJ 491; Enchodus sp. 2: Pz.UERJ 485; Pz.UERJ 492; Enchodus libycus: FPH-01-82; FPH-02-12; FPH-01 679; FPH-01 742; FPH-01 677; FPH-01 810; FPH-01 808; FPH-01 809; DGM 642-P; Enchodus oliveirai: DGM 643-P; Enchodus subaequilatelaris: DGM 644-P; MN 4329-V; Enchodus longipectoralis: DGM 501-P; Enchodus venator: MNHN DTS 156, MNHN DTS 157 d g; MNHN DTS $158 \mathrm{~d}$ g; MNHN DTS 160; MNHN DTS 148; MNHN DTS
138 d g; MNHN DTS 149; MNHN DTS 141 d g; MNHN DTS 159 d g; MNHN DTS 155; MNHN DTS 190 d g; MNHN DTS 143; Eurypholis boisseiri: Pz.UERJ 493; NHM P. 48; NHM P. 63323; Eurypholis longidens: NHM P. 48084; NHM P. 409507; Eurypholis pulchellus: NHM P. 1703; Eurypholis sp.: NHM P. 47317; Rharbichthys cf. ferox: Pz.UERJ 448 a b; Pz.UERJ 451; Pz.UERJ 452; Rharbichthys ferox: MNHN DTS 118 d g; MNHN DTS 162 d g; MNHN DTS 130 d g; MNHN DTS $81 \mathrm{~d}$; ; MNHN DTS $86 \mathrm{~d}$ g; MNHN DTS 164 d g; MNHN DTS 97 d g; MNHN DTS 119 g d; MNHN DTS $163 \mathrm{~g} \mathrm{~d}$; MNHN DTS 165; MNHN DTS 166; MNHN DTS 167; MNHN DTS 71; MNHN DTS 161; MNHN DTS $72 \mathrm{~d}$ g; MNHN DTS $126 \mathrm{~d}$ g.

Dercetidae - Benthesikyme armatus: NHM P. 2109; Benthesikyme gracilis: NHM P. 48085; NHM P. 49539; NHM P. 48087; NHM P. 1902; NHM P. 47359; NHM P. 49538; NHM P. 9170; NHM P. 47360; NHM P. 4738; NHM P. 46553; NHM P. 48088; NHM P. 46533; NHM P. 48086; Benthesikyme rostralis: MNHN SHA 499; MNHN SHA 501; MNHN SHA 505; MNHN SHA 513; MNHN SHA 578; MNHN SHA 2840; MNHN SHA 2849; Benthesikyme sp.: NHM P. 4019; Brazilodercetis longirostris Pz.UERJ 447; Pz.UERJ 471; Pz.UERJ 472; Pz.UERJ 473; Pz.UERJ 474; Pz.UERJ 475; Pz.UERJ 476; Pz.UERJ 477; Pz.UERJ 478; Pz.UERJ 495.; Dercetis elongatus 4018; 49536; NHM P. 15513; NHM P. 43098; NHM P. 4134; NHM P. 4132-33; NHM P. 41198; NHM P. 49793; NHM P. 12895; NHM P. 43512; NHM P. 31075-82.; Dercetis sp. NHM P. 49740; NHM P. 48155; Dercetis triqueter NHM P. 4852; NHM P. 49541; NHM P. 49535; NHM P. 4007; NHM P. 46524; NHM P. 4963; NHM P. 49537; NHM P. 47362; NHM P. 47361, MNHN SHA 520; MNHN SHA 523; MNHN SHA 572; MNHN SHA 2192 d g; MNHN SHA 2317; MNHN SHA 2444; MNHN SHA 3107; Rhynchodercetis cf. gracilis NHM P. 63235 a/b; NHM P. 63332; NHM P. $63246 \mathrm{a} / \mathrm{b}$; NHM P. $62677 \mathrm{a} / \mathrm{b}$; Rhynchodercetis cf. yovanovitchi NHM P. 62678; NHM P. 63236 a/b; NHM P. 63599; NHM P. 63261; NHM P. 62690; NHM P. 63262; Rhynchodercetis gortanii NHM P. 10913; Rhynchodercetis hakelensis NHM P. 6001; NHM P. 4739; NHM P. 4683; NHM P. 4866; Rhynchodercetis serpentinus NHM P. 51939; Rhynchodercetis yovano- 
vitchi MNHN DTS 8; MNHN DTS $9 \mathrm{~d}$ g; MNHN DTS $10 \mathrm{~d}$ g; MNHN DTS 14; MNHN DTS 15; MNHN DTS 20; MNHN DTS 21; MNHN DTS 22; MNHN DTS 23; MNHN DTS 123; MNHN DTS 47; MNHN DTS 175; MNHN DTS 174; MNHN DTS 186; MNHN DTS 40; MNHN DTS 302; MNHN DTS 303; MNHN DTS 304; MNHN DTS 306; MNHN DTS 307; MNHN DTS 308; MNHN DTS 309; MNHN DTS $261 \mathrm{dg}$; MNHN DTS 96 d g; MNHN DTS $43 \mathrm{dg}$; MNHN DTS 310; MNHN DTS 189; MNHN DTS $176 \mathrm{dg}$; MNHN DTS177 d g; MNHN DTS 2; MNHN DTS 7; MNHN DTS 41; MNHN DTS 262; MNHN DTS $6 \mathrm{~d}$ g; MNHN DTS 263 a b.

Apateopholidae - Apateodus striatus NHM P. 61919; NHM P. 49799; NHM P. 4090-1; NHM P. 49821; NHM P. 12899; NHM P. 12898; NHM P. 33309; NHM P. 49067; NHM P. 479224; NHM P. 10058; NHM P. 49070; Apateopholis laniatus NHM P. 4745; NHM P. 4026; NHM P. 4870; NHM P. 63263; NHM P. 4869.

Cimolichthyidae - Cimolichthys levesiensis NHM P. 4039; NHM P. 4026; NHM P. 1810a; NHM P. 1811; NHM P. 38113; NHM P. 5491.

Prionolepididae - Prionolepis cataphhractus NHM P. 4864; NHM P. 9966; NHM P. 9967; NHM P. 9968; NHM P. 9970; NHM P. 47516; NHM P. 4871; NHM P. 47332; NHM P. 4006; Prionolepis laniatus NHM P. 39234.
Ichthyotringidae - Ichthyotringa sp. NHM P. 6015; NHM P. 14204; NHM P. 9996; NHM P. 48089 a/b; NHM P. 1882; NHM P. 49544; NHM P. 48092; NHM P. 48155; Ichthyotringa africana MNHN DTS 225; MNHN DTS 226; MNHN DTS 227 g d; MNHN DTS 228 d g.; Ichthyotringa damoni NHM P. 47367; NHM P. 4849; Ichthyotringa furcata NHM P. 49523; NHM P. 49525; NHM P. 48090; NHM P. 49545; NHM P. 48091; NHM P. 47363; NHM P. 48144; NHM P. 47364.

Halecidae - Halec sternbergi NHM P. 9004; NHM P. 9004; NHM P. 5732; Halec eupterygius NHM P. 11102; NHM P. 43388; NHM P. 32336; NHM P. 4289; NHM P. 43392; NHM P. 10920; NHM P. 32237; Halec rugosus NHM P. 13899; Phylactocephalus microlepis NHM P. 4757; NHM P. 105; NHM P. 47318; NHM P. 9151; Hemisaurida hakelensis NHM P. 48779; NHM P. 48780 .

Atolvorator longipectoralis Pz.UERJ 486; Pz.UERJ 487; Pz.UERJ 496 a e b; Pz.UERJ 508 a e b; Pz.UERJ 509; Pz.UERJ 510.

Sardinioides minimus NHM P. 52513; NHM P. 52511; NHM P. 52512; NHM P. 52504 a.

Protostomias maroccanus MNHN DTS $18 \mathrm{~d}$ g; MNHN DTS $122 \mathrm{~d}$ g; MNHN DTS $172 \mathrm{~d}$ g; MNHN DTS 178; MNHN DTS 179 d g; MNHN DTS 184; MNHN DTS 77; MNHN DTS 381. 
APPENDIX II

Data matrix of the cladistic analysis of Enchodontoidei.

\begin{tabular}{|c|c|c|c|c|c|c|c|c|c|}
\hline Taxa / Characters & $1-5$ & $6-10$ & $11-15$ & $16-20$ & $21-25$ & $26-30$ & $31-35$ & $36-40$ & $41-45$ \\
\hline Sardinioides & 00000 & $000 ? 1$ & $00 ? 00$ & $100 ? ?$ & 00000 & $1 ? 0 ? 1$ & 10000 & 01000 & 10001 \\
\hline Protostomias & 00000 & 10000 & $00 ? 00$ & 00100 & $1 ? 1 ? 0$ & 01000 & 00110 & 00001 & 00100 \\
\hline Trachinocephalus & 00030 & 00000 & 11000 & 00000 & 01000 & 00100 & $010 ? 0$ & $001 ? 2$ & 00210 \\
\hline Ichthyotringa & 11100 & $001 ? 0$ & $? 0001$ & $0 ? 000$ & $0 ? 000$ & $? ? 111$ & $? 0010$ & 00100 & $? 0200$ \\
\hline Apateopholis & $0011 ?$ & $00 ? ? 0$ & $? 0000$ & $1 ? 1 ? 0$ & 00111 & $? ? 011$ & 00010 & 00100 & 00001 \\
\hline Apateodus & $? 0000$ & $00 ? ? 0$ & 10100 & 00000 & $1000 ?$ & $0 ? ? 11$ & 10010 & 00000 & 00200 \\
\hline Cimolichthys & 00021 & $00 ? 10$ & 00000 & 10000 & 00011 & $0 ? 111$ & 01001 & 00000 & 10200 \\
\hline Apuliadercetis & 21101 & $00 ? ? 0$ & 00011 & 00000 & $1 ? 0 ? 0$ & 13100 & 10010 & 01112 & 00010 \\
\hline Benthesikyme & $2 ? 10 ?$ & $00 ? ? 0$ & $1 ? 000$ & $0 ? 010$ & $1 ? 0 ? ?$ & $1 ? ? 11$ & $? ? 010$ & 00113 & $0 ? ? 1 ?$ \\
\hline Brazilodercetis & $? 112 ?$ & $00 ? 00$ & 10000 & 00000 & $1 ? 1 ? ?$ & 13000 & 10110 & 00112 & 01111 \\
\hline Caudadercetis & $2110 ?$ & $00 ? ? 0$ & $0 ? ? ? 0$ & $001 ? ?$ & $1 ? 1 ? ?$ & $? ? 1 ? 0$ & $100 ? 0$ & $0 ? ? ? 2$ & $? 0210$ \\
\hline Cyranichthys & $1112 ?$ & $? ? ? ? 0$ & 10000 & 00000 & $1 ? 0 ? ?$ & $1 ? ? ? ?$ & $? ? 010$ & $0 ? 010$ & $0 ? ? 10$ \\
\hline Dercetis & 21110 & $00 ? ? 1$ & 10000 & 00000 & $1 ? 0 ? ?$ & 12111 & $? 0010$ & 01112 & 00111 \\
\hline Dercetoides & $2111 ?$ & $? ? ? 10$ & $00 ? 10$ & 10100 & $101 ? ?$ & $1 ? 000$ & 10010 & $0 ? 113$ & 00101 \\
\hline Hastichthys & $2110 ?$ & $? ? ? 10$ & 01010 & 10000 & $1 ? 0 ? ?$ & 12111 & 10111 & 00110 & 01001 \\
\hline Nardodercetis & 21100 & $00 ? ? 0$ & $0 ? 000$ & $101 ? 0$ & $0 ? ? ? ?$ & $1 ? 000$ & $? 0110$ & $0 ? 100$ & 01001 \\
\hline Ophidercetis & $2110 ?$ & $21 ? 00$ & 10000 & 00000 & $1 ? 0 ? ?$ & 12111 & $? 0010$ & 01112 & 00210 \\
\hline Pelargorhynchus & $1113 ?$ & $? ? ? ? 0$ & 00000 & 10110 & $1 ? 1 ? ?$ & $1 ? 11 ?$ & $? ? 001$ & 00110 & 00201 \\
\hline Rhynchodercetis & 21100 & $00 ? 00$ & 01001 & 10100 & $1 ? 1 ? ?$ & $1 ? 010$ & 10110 & 00110 & 01001 \\
\hline Robertichthys & $211 ? 0$ & $10 ? ? ?$ & $? 0 ? ? 0$ & ????? & $1 ? ? ? 0$ & $1 ? ? 1 ?$ & 10010 & 00012 & 01210 \\
\hline Prionolepis & 00031 & $00 ? ? 0$ & 10000 & 12000 & 00011 & $1 ? 110$ & 11000 & 00110 & 00111 \\
\hline Rharbichthys & $0002 ?$ & $21 ? 00$ & $10 ? 00$ & $0 ? 110$ & $0 ? 0 ? ?$ & $? ? 1 ? 1$ & 10010 & 01100 & 00210 \\
\hline Palaeolycus & $1002 ?$ & $21 ? 1 ?$ & $? 0 ? 10$ & $? ? 1 ? ?$ & $1 ? 1 ? ?$ & $? ? 110$ & $? ? 000$ & 10010 & $? 0010$ \\
\hline Eurypholis & 00011 & $21 ? 10$ & 10000 & 12100 & 00011 & 12110 & 11001 & 11110 & 00200 \\
\hline Saurorhamphus & $1111 ?$ & $? 0 ? 10$ & 10000 & 12100 & $1 ? 011$ & $1211 ?$ & 10001 & $1 ? 013$ & 00000 \\
\hline Enchodus & $0003 ?$ & ????? & $? ? ? ? 0$ & $? ? ? ? 0$ & 0???? & $? ? 11 ?$ & $10 ? ? ?$ & $? ? 000$ & 10010 \\
\hline Parenchodus & $0003 ?$ & $2 ? 1 ? 0$ & 10110 & 12100 & $1010 ?$ & $1 ? 011$ & $? 1001$ & 01003 & 00210 \\
\hline Halec & 00010 & $00 ? 10$ & 10000 & 10100 & $001 ? ?$ & $0 ? 111$ & 11001 & 00102 & 10110 \\
\hline Hemisaurida & 00000 & $00 ? 1 ?$ & $10 ? 10$ & $? ? ? ? 0$ & $00 ? ? ?$ & $1 ? 011$ & 11000 & 00103 & 10111 \\
\hline Phylactocephalus & 00010 & 00010 & 00000 & $? ? ? ? 0$ & $011 ? ?$ & ??11? & 01001 & 00102 & 10111 \\
\hline Nardorex & $? 0021$ & 00111 & 10001 & 00001 & $0 ? 01 ?$ & $1311 ?$ & $? ? 000$ & 01013 & 00000 \\
\hline Serrilepis & 00030 & $000 ? 0$ & 10100 & 10000 & $1 ? 111$ & 00111 & $? 0011$ & $0 ? 103$ & 10101 \\
\hline Atolvorator & 00000 & ??0?? & $? 1100$ & 01100 & 10100 & 02011 & 00010 & $? 0100$ & 10000 \\
\hline Yabrudichthys & 00110 & $101 ? ?$ & $? 0000$ & $? ? ? ? 0$ & $1010 ?$ & $? ? 000$ & $? 1010$ & $0 ? 1 ? 0$ & 00000 \\
\hline
\end{tabular}


APPENDIX II (continuation)

\begin{tabular}{|c|c|c|c|c|c|c|c|c|}
\hline Taxa / Characters & $46-50$ & $51-55$ & $56-60$ & $61-65$ & $66-70$ & $71-75$ & $76-80$ & $81-87$ \\
\hline Sardinioides & 00000 & 00000 & 00000 & 00000 & 01100 & 01001 & 01010 & 0000000 \\
\hline Protostomias & 00001 & 10000 & 00000 & $001 ? 0$ & $1000 ?$ & 00000 & $00 ? 01$ & 0001000 \\
\hline Trachinocephalus & 11000 & 00000 & 20000 & 00000 & 00011 & 00000 & 10000 & 0000000 \\
\hline Ichthyotringa & $010 ? 0$ & $1001 ?$ & 10001 & 00010 & 01110 & 01001 & 00000 & 0000000 \\
\hline Apateopholis & 00020 & $1001 ?$ & 11101 & 01110 & 01000 & 01101 & 11000 & $0 ? 01000$ \\
\hline Apateodus & 00020 & 00100 & 30001 & 00010 & ????? & $? ? ? ? ?$ & $? ? ? 0 ?$ & ??????? \\
\hline Cimolichthys & 01021 & $0001 ?$ & 10001 & $011 ? ?$ & $000 ? 0$ & $010 ? 1$ & $? 10 ? 0$ & $? 101220$ \\
\hline Apuliadercetis & 00020 & 00001 & 10010 & $000 ? 0$ & 00011 & 11001 & 21000 & 0101310 \\
\hline Benthesikyme & $0 ? ? ? 0$ & $? ? ? ? ?$ & $? ? ? ? ?$ & $? ? ? ? ?$ & $? ? ? 1 ?$ & $? 100 ?$ & $? ? ? 0 ?$ & $01 ? 13 ? 0$ \\
\hline Brazilodercetis & 00000 & 00000 & 40010 & $0000 ?$ & $? ? ? ? 1$ & $11 ? ? ?$ & ????? & ???132? \\
\hline Caudadercetis & 00020 & $0000 ?$ & $10 ? 00$ & $00 ? ? 0$ & $? 0011$ & $11 ? 00$ & $01 ? 01$ & 1111000 \\
\hline Cyranichthys & $0 ? ? ? ?$ & $? ? ? ? ?$ & 10010 & $00 ? 0 ?$ & $? ? ? ? 0$ & $1 ? ? ? ?$ & $? 11 ? ?$ & $? ? ? 1120$ \\
\hline Dercetis & 01020 & $1001 ?$ & 10000 & 00000 & $? 0010$ & 11000 & 01100 & 0101320 \\
\hline Dercetoides & 01021 & $0000 ?$ & 30000 & 01001 & 00011 & 11000 & 01000 & 0111310 \\
\hline Hastichthys & 01020 & 00000 & 10010 & $0000 ?$ & 00011 & $1100 ?$ & 01001 & 0111310 \\
\hline Nardodercetis & 00020 & 00000 & $? ? ? 1 ?$ & $00 ? 00$ & 00011 & 11001 & $10 ? ? 0$ & 0011310 \\
\hline Ophidercetis & 01010 & 00000 & 30000 & 00000 & $0001 ?$ & 11000 & 20101 & $0 ? ? 1120$ \\
\hline Pelargorhynchus & $000 ? 1$ & $? 00 ? ?$ & $1 ? 000$ & $? 010 ?$ & $? 0 ? ? 0$ & $11 ? ? 1$ & $? 11 ? 0$ & $? ? ? 0220$ \\
\hline Rhynchodercetis & 00000 & $0001 ?$ & 10000 & 00000 & 00011 & $1 ? 000$ & 21100 & 0111310 \\
\hline Robertichthys & $010 ? 0$ & $? ? ? ? ?$ & 10010 & $001 ? ?$ & $000 ? ?$ & $11 ? ? 1$ & $2 ? ? ? ?$ & $? ? ? 0310$ \\
\hline Prionolepis & 11000 & $000 ? ?$ & 11001 & $001 ? 1$ & 01010 & 01111 & 21000 & 0000000 \\
\hline Rharbichthys & 00000 & 10100 & 10000 & 01000 & $0110 ?$ & 00001 & 21000 & 1001410 \\
\hline Palaeolycus & 01011 & $1010 ?$ & $? 1001$ & $0110 ?$ & $0001 ?$ & 01001 & 20001 & 0??1001 \\
\hline Eurypholis & 00001 & $011 ? 1$ & 11101 & 11100 & 01110 & 01000 & 00000 & 0001111 \\
\hline Saurorhamphus & 01001 & 11111 & 11101 & 11100 & 01010 & 01000 & 20001 & 0000111 \\
\hline Enchodus & $? 1110$ & $? 01 ? ?$ & 11000 & 01100 & $0111 ?$ & 01001 & $21 ? ? 1$ & $00 ? 1001$ \\
\hline Parenchodus & 01121 & 10101 & 11001 & 01101 & 11001 & 00101 & 01101 & 0101001 \\
\hline Halec & 01001 & $000 ? ?$ & 11001 & 01010 & 01110 & 01001 & 01000 & 0000000 \\
\hline Hemisaurida & 00020 & $0001 ?$ & 20100 & 00000 & 01110 & 01001 & 21000 & 0001000 \\
\hline Phylactocephalus & 00021 & $0000 ?$ & 11001 & 01000 & 01110 & 01111 & 01000 & 0000000 \\
\hline Nardorex & 00010 & 10000 & 00110 & 00100 & $01 ? 10$ & 00001 & 00001 & $? ? ? 1000$ \\
\hline Serrilepis & $010 ? 1$ & 10101 & 11001 & 01111 & 01110 & 01001 & 01010 & 0100000 \\
\hline Atolvorator & 01020 & 00100 & 10000 & 00100 & 10110 & 01001 & $1000 ?$ & $? 001000$ \\
\hline Yabrudichthys & $000 ? 1$ & $1010 ?$ & $1111 ?$ & 00110 & $0100 ?$ & 01001 & 21110 & 0101000 \\
\hline
\end{tabular}




\section{APPENDIX III}

List of characters used in the phylogenetic analysis of $†$ Enchodontoidei.

1. Body length: slightly elongate [lesser than or equal to 1:10] (0);

elongate [from 1:11 to $1: 15$ ] (1); very elongate [higher than $1: 15$ ] (2).

2. Head height: deep (0); low (1).

3. Snout length: short (0); long (1).

4. Dermal pattern on skull roof: smooth (0); only with tubercles (1); only with ridges (2); tubercles + ridges (3).

5. Vomerine teeth: absent (0); present (1).

6. Number of teeth on dermopalatine: two or more (0); none (1); single (2).

7. Dermopalatine length: twice or more times longer than its tooth $(0)$; equal-sized or shorter than its tooth (1).

8. Antorbital: present (0); absent (1).

9. Nasal: present (0); absent (1).

10. Anterior extremity of mesethmoid: acute (0); bifid (1).

11. Posterior extremity of mesethmoid: bifid (0); acute (1); straight (2).

12. Autosphenotic spine: straight (0); posteriorly curved (1).

13. Suture between frontals: slightly sinuous (0); markedly sinuous (1).

14. Posterior border of frontal: behind the autosphenotic spine (0); at the level of the autosphenotic spine (1).

15. Shape of the post-orbital border: concave (0); convex (1).

16. Parietal length: long [length equal or larger than its height (0)]; short [length smaller than its height (1)].

17. Supraorbital sensory canal in the skull roof: covered (0); exposed (1).

18. Extension of the supraoccipital: not separating parietals (0); separating parietals (1).

19. Supraoccipital crest: present (0); absent (1).

20. Supraoccipital with two well-delimited regions: absent (0); present (1).

21. Extension of pterotic: not projecting backwards beyond the level of occiput; (0) projecting beyond the occiput (1).

22. Dilatator fossa: unroofed (0); roofed (1).

23. Exposition of the post-temporal fossa: roofed (0); unroofed (1).

24. Orbitosphenoid: present (0); absent (1).

25. Basisphenoid: present (0); absent (1).

26. Supraorbital: present (0); absent (1).

27. Lachrymal shape: subtriangular (0); suboval (1); trapezoidal (2); rod-shaped (3).

28. Position of the mandibular suspensorium: inclined (0); vertical (1).

29. Ectopterygoid: toothless (0); toothed (1).

30. Endopterygoid: toothless (0); toothed (1).

31. Placement of articular facet for the hyomandibula: posteroventral (0); ventral (1).

32. Number of articular facet for the hyomandibula: a continuous facet (0); two facets (1).

33. Premaxilla: toothed (0); toothless (1).

34. Posterior extension of the premaxilla: reaching the orbit (0); not reaching the orbit (1).

35. Dermal pattern on premaxilla: smooth (0), ornamented (1).

36. Fenestra in the premaxilla: absent (0); present (1).

37. Ascending process of the premaxilla: absent (0); present (1).

38. Maxilla: toothless (0); toothed (1).

39. Placement of the maxilla: over the premaxilla (0); behind the premaxilla (1).

40. Teeth on upper jaw: only straight (0); absent (1); curved + straight (2); only curved (3)

41. Supramaxilla: absent (0); present (1).

42. Mandible length: equal to the snout (0); shorter than the snout (1). 
43. Teeth on mandible: only straight (0); only curved (1); curved + straight (2).

44. Teeth size on upper jaw: absent or with same height (0); with different height (1).

45. Teeth size on mandible: different height (0); equal height (1).

46. Rows of teeth on upper jaw: single (0); two or more (1).

47. Rows of teeth on mandible: single (0); two or more (1).

48. Anteroventral prongs on dentary: absent (0); present (1).

49. Mandibular sensory canal: enclosed by bone (0); partially open (1); open (2).

50. Mandibular dermal pattern: smooth (0), ornamented (1).

51. Flange on anguloarticular: present (0); absent (1).

52. Quadrate-mandibular articulation: exposed (0); hidden (1).

53. Articular facet for the quadrate: shallow (0); deep (1).

54. Retroarticular process: present (0), absent (1).

55. Ornamentation in the infraorbital bones: smooth (0), ornamented (1).

56. Preopercle shape: L-shaped (0); triangular (1); crescent-shaped (2); rod-shaped (3); pipe-shaped (4).

57. Preopercular dermal pattern: smooth (0); ornamented (1).

58. Posteroventral spine in the preopercle: absent or reduced (0), well-developed (1).

59. Dimension of the opercle: deeper than long (0); longer than deep (1).

60. Opercle crest: absent (0); (1) present.

61. Spine on posterior border of the opercle: absent (0); present (1).

62. Opercular and subopercular dermal pattern: smooth (0); ornamented (1).

63. Interopercle: present (0); absent (1).

64. Mesocoracoid: absent (0); present (1).

65. Scapula and coracoid: individualized (0); co-ossified (1).

66. Supraneurals: present (0); absent (1).

67. Total number of vertebrae: more than $50(0)$; equal or minus than 50 (1).

68. Number of caudal vertebrae: more than 20 (0); equal or minus than 20 (1).

69. Ribs: extending to the pelvic fin origin (0); surpassing the pelvic fin origin (1).

70. Transverse processes: one pair (0); two pairs (1).

71. Neural spines: well-developed [their length surpassing the length of the vertebral centrum] (0); very reduced [their length equal or minus than half of the length of the vertebral centrum] (1).

72. Neural spines bifid in the abdominal region: present (0); absent (1).

73. Distribution of epipleurals: extending to more than a half of the body (0); up to half of the body (1).

74. Distribution of epineurals: extending to more than a half of the body (0); up to half of the body (1).

75. Position of the pectoral fin: high [last fin-ray placed at the level of the ventral border of the opercle or a little above (0)]; low [last fin-ray placed below the level of the ventral border of the opercle (1)].

76. Orientation of the pectoral fin base: vertical (0), horizontal (1), inclined (2).

77. Origin of the pelvic fin: anterior to the dorsal fin (0); opposite or posterior to the dorsal fin (1).

78. Dorsal fin length: short [lesser than 20 rays (0]; long [more than 20 rays] (1).

79. Shape of the first proximal pterygiophore of the dorsal fin: different from the remnants $(0)$; all equal in shape (1).

80. Anal fin length: short [up to 15 rays (0)]; long [more than 15 rays (1)].

81. Anal fin edge: not serrated (0); serrated (1).

82. Fusion of hypurals: free (0); fused (1).

83. Contact between hypurals 2-3: free (0); with convoluted suture (1).

84. Body scales: present (0); absent (1).

85. Flank scutes: absent (0); triangular (1); cordiform (2); tripartite (3); retangular (4).

86. Number of rows of scutes on flanks: absent (0); single (1); two or more (2).

87. Middorsal scutes: absent (0); present (1). 